\title{
Characterization of submicron aerosols influenced by biomass burning at a site in the Sichuan Basin, southwestern China
}

\author{
Wei Hu${ }^{1, \mathrm{a}}$, Min $\mathrm{Hu}^{1}$, Wei-Wei Hu${ }^{1, \mathrm{~b}}$, Hongya Niu ${ }^{1, \mathrm{c}}$, Jing Zheng ${ }^{1}$, Yusheng $\mathrm{Wu}^{1}$, Wentai Chen ${ }^{1}$, Chen Chen ${ }^{1}$, \\ Lingyu Li ${ }^{1}$, Min Shao ${ }^{1}$, Shaodong Xie ${ }^{1}$, and Yuanhang Zhang ${ }^{1}$ \\ ${ }^{1}$ State Key Joint Laboratory of Environmental Simulation and Pollution Control, College of Environmental Sciences and \\ Engineering, Peking University, Beijing 100871, China \\ ${ }^{a}$ now at: Graduate School of Environmental and Symbiotic Sciences, Prefectural University of Kumamoto, \\ Kumamoto 862-8502, Japan \\ ${ }^{b}$ now at: Cooperative Institute for Research in Environmental Sciences, University of Colorado, Boulder, CO 80309, USA \\ ${ }^{c}$ now at: Hebei Collaborative Innovation Center of Coal Exploitation, Hebei University of Engineering, Handan 056038, \\ Hebei, China
}

Correspondence to: Min Hu (minhu@pku.edu.cn)

Received: 3 February 2016 - Published in Atmos. Chem. Phys. Discuss.: 9 May 2016

Revised: 3 October 2016 - Accepted: 11 October 2016 - Published: 27 October 2016

\begin{abstract}
Severe air pollution in Asia is often the consequence of a combination of large anthropogenic emissions and adverse synoptic conditions. However, limited studies on aerosols have been conducted under high emission intensity and under unique geographical and meteorological conditions. In this study, an Aerodyne high-resolution time-offlight aerosol mass spectrometry (HR-ToF-AMS) and other state-of-the-art instruments were utilized at a suburban site, Ziyang, in the Sichuan Basin during December 2012 to January 2013. The chemical compositions of atmospheric submicron aerosols $\left(\mathrm{PM}_{1}\right)$ were determined, the sources of organic aerosols (OA) were apportioned, and the aerosol secondary formation and aging process were explored as well. Due to high humidity and static air, $\mathrm{PM}_{1}$ maintained a relatively stable level during the whole campaign, with the mean concentration of $59.7 \pm 24.1 \mu \mathrm{g} \mathrm{m}^{-3}$. OA was the most abundant component ( $36 \%$ ) in $\mathrm{PM}_{1}$, characterized by a relatively high oxidation state. Positive matrix factorization analysis was applied to the high-resolution organic mass spectral matrix, which deconvolved OA mass spectra into four factors: low-volatility (LV-OOA) and semivolatile oxygenated OA (SV-OOA), biomass burning (BBOA) and hydrocarbon-like OA (HOA). OOA (sum of LV-OOA and SV-OOA) dominated $\mathrm{OA}$ as high as $71 \%$. In total, secondary inorganic and organic formation contributed $76 \%$ of $\mathrm{PM}_{1}$. Secondary inorganic species correlated well (Pearson $r=0.415-0.555, p<0.01$ )
\end{abstract}

with relative humidity (RH), suggesting the humid air can favor the formation of secondary inorganic aerosols. As the photochemical age of OA increased with higher oxidation state, secondary organic aerosol formation contributed more to OA. The slope of OOA against $\mathrm{O}_{x}\left(=\mathrm{O}_{3}+\mathrm{NO}_{2}\right)$ steepened with the increase of RH, implying that, besides the photochemical transformation, the aqueous-phase oxidation was also an important pathway of the OOA formation. Primary emissions, especially biomass burning, resulted in high concentration and proportion of black carbon (BC) in $\mathrm{PM}_{1}$. During the episode obviously influenced by primary emissions, the contributions of BBOA to OA $(26 \%)$ and $\mathrm{PM}_{1}(11 \%)$ were much higher than those $(10-17 \%, 4-7 \%)$ in the clean and other polluted episodes, highlighting the significant influence of biomass burning.

\section{Introduction}

With its dense population and rapid economic development in the past decades, the Sichuan Basin suffers from serious fine particle pollution and has become one of the most polluted regions in China (Chen and Xie, 2012). The basin, located in the southwest of China, is one of the most populous regions in China and the world, with a population density of approximate 400 people per square kilometer. The 
two megalopolises in the basin, Chongqing and Chengdu, with the largest populations of about 30 and 14 million, respectively, have been seeing increases in industrial added values by an annual rate of over $10 \%$. High emissions of gaseous and particulate pollutants, such as volatile organic compounds (VOCs), $\mathrm{SO}_{2}$, organic carbon (OC), black carbon (BC) and fine particles $\left(\mathrm{PM}_{2.5}\right)$, are found in the Sichuan Basin over China (He, 2012). Adversely influenced by the particular topographic condition, the Sichuan Basin is within the region of the lowest wind speed and relatively high humidity over China all year round (Chen and Xie, 2013; Yang et al., 2011). The annual mean value of the aerosol optical depth in the Sichuan Basin from 2000 to 2010 was the highest across China, reflecting the importance of large topography in aerosol accumulation (Luo et al., 2014). Under the stable weather system, high relative humidity (RH) in Chengdu and high RH, high pressure and low wind speed in Chongqing resulted in the low visibility. The air quality has been aggravated in the Sichuan Basin for more intense anthropogenic emissions since the year 2000 (Chen and Xie, 2013). The unique geographical and meteorological conditions in the region favor the accumulation of local and regional atmospheric pollutants (Yang et al., 2011), making environmental threats in Sichuan more severe.

Degraded air quality and variability of fine particle concentrations in the Sichuan Basin arise from substantial local anthropogenic emissions and regional photochemistry, and they are aggravated by topographical and meteorological conditions. Yang et al. (2011) reported that during cold periods, high $\mathrm{PM}_{2.5}$ levels at 129 and $156 \mu \mathrm{g} \mathrm{m}^{-3}$, of which organics and sulfate accounted for over $50 \%$, were observed in Chengdu and Chongqing, respectively. High $\mathrm{SO}_{4}^{2-} / \mathrm{NO}_{3}^{-}$ ratio indicated that local and stationary sources were predominant in the region where high-sulfur coal fuels are regularly consumed in large quantity; high $\mathrm{K}^{+}$concentration (more than $6 \mu \mathrm{g} \mathrm{m}^{-3}$ ) in Chongqing during the winter suggested that biomass burning from residential heating also accounted for an important source of pollution (Yang et al., 2011; Cao et al., 2012). Wang et al. (2013) concluded that organics, ammonium bisulfate, ammonium nitrate and moisture in fine particles contributed more than $86 \%$ to the light-extinction coefficient in Chengdu; biomass burning, coal combustion and vehicular and industrial emissions were the main contributors to both $\mathrm{PM}_{2.5}$ and the light-scattering coefficient. Secondary formation from biomass burning emissions can significantly influence local and regional air quality, atmospheric processes and even climate change (Niu et al., 2016). Though several published papers focused on aerosol chemical and physical properties in the Sichuan Basin, highly timeresolved studies are rarely conducted. Due to the episodic nature of primary emissions and meteorological conditions, it is necessary to explore secondary formation in the influence of biomass burning by using high time resolution aerosol mass spectrum.
Organic aerosols $(\mathrm{OA})$ are very significant components in fine particulate matter (Zhang et al., 2007). Several results on the compositions and sources of OA in the Sichuan Basin have also been reported. Wang et al. (2006) found that the concentration of OA quantified at the molecular level was extremely high $\left(9.7 \mu \mathrm{g} \mathrm{m}^{-3}\right)$ in winter in Chongqing because of its active industrialization and urbanization. Anthropogenic sources, such as coal combustion, cooking and vehicle emissions, contributed to OA primarily. High levels of levoglucosan, as a key tracer of biomass burning, which contributed approximately $90 \%$ of total identified sugars $\left(700 \mathrm{ng} \mathrm{m}^{-3}\right)$, were most likely emitted from residential burning (Wang et al., 2006). L. Li et al. (2013) concluded that approximately $15-21 \%$ of the OC could be apportioned to biogenic sources and processes, e.g., biomass burning, isoprene oxidation products and fungal spores, at a forest site and an urban site in Ya' an in the Sichuan Basin, during the summer of 2010. High organic and elemental carbon (OC and EC) concentrations and OC / EC ratios were observed in urban Chengdu, which revealed that the formation of secondary organic carbon contributed to OC as $55 \%$ based on the EC tracer method (Zhang et al., 2008). These results suggested the important contributions of biomass burning and other primary emissions, as well as secondary formation to OA in the Sichuan Basin.

Many studies refer to secondary organic aerosols (SOA), as a product of atmospheric processes including the oxidation of VOCs, shifting of chemical equilibrium, re-partitioning of semivolatile species, adsorption/absorption through heterogeneous physical and chemical processes, and cloud physicochemical processes (Kroll et al., 2005; Hallquist, et al., 2009). SOA makes up about $20-80 \%$ of OA in the atmosphere (Carlton et al., 2009), yet the formation mechanisms of SOA remain essentially speculative, causing discrepancies between observed SOA and model simulations. Which precursors and chemical mechanisms are important therefore remains unclear (Hallquist et al., 2009).

The employment of aerosol mass spectrometry (AMS, Aerodyne Research Inc., USA) not only can obtain highresolution chemical composition of submicron aerosols but also can allow source apportionment of primary organic aerosols (POA) and SOA (Ng et al., 2010). OA mass spectral matrix from Aerodyne AMS analyzed with a positive matrix factorization (PMF) technique (Paatero, 1997) resolved OA into several factors: oxygenated organic aerosol (OOA) factors described as low-volatility and semivolatile OOA (LV-OOA and SV-OOA), hydrocarbon-like (HOA), biomass burning (BBOA), cooking (COA) and coal combustion OA (CCOA), etc. (Jimenez et al., 2009; Ng et al., 2011; Hu et al., 2013 , 2016). Noted that COA refers to OA emitted by food during cooking activities, with no relation to fuels for cooking (Allan et al., 2010). HOA, BBOA, COA and CCOA could be considered as POA; the OOA component has been shown to be a good surrogate SOA in many studies (Ng et al., 2010). Discrimination of different OA components can favor quan- 


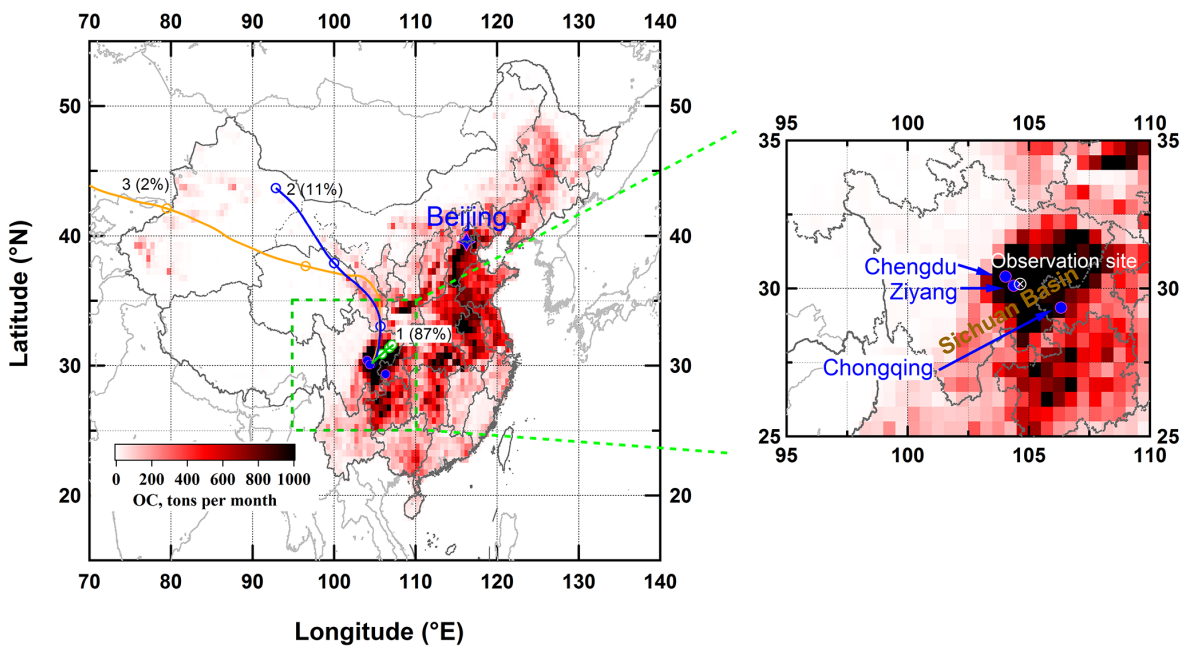

Figure 1. Location of the observation site in Ziyang in the Sichuan Basin. Back trajectories of air masses at the site calculated by HYSPLIT model are illustrated as lines (circles marking $24 \mathrm{~h}$ intervals). The map of China is color-coded according to residential OC emissions in January 2010 modeled by Multi-resolution Emission Inventory for China (MEIC, http://www.meicmodel.org).

tifying the primary and secondary contributions and probing into secondary formation mechanisms and aging processes of OA (Ulbrich et al., 2009).

The aging process plays an important role in the life cycle of atmospheric aerosols. The chemical composition, hygroscopicity and solubility of atmospheric aerosols are varied due to the aging process, which not only influences their optical properties and capability to form clouds but also changes their impacts on environment, climate and human health. The aging process of $\mathrm{OA}$ can be characterized by some metrics and tools, including $\mathrm{C} / \mathrm{H} / \mathrm{O}$ atomic ratios, van Krevelen diagram (VK diagram), OA / OC ratio, OA / $\Delta \mathrm{CO}$, average carbon oxidation state $\left(\overline{\mathrm{OS}_{\mathrm{C}}}\right)$ and the abundance of characteristic fragment ions ( $f_{43}$ and $f_{44}$ ), to provide the basis for model simulation of SOA formation (de Gouw and Jimenez, 2009; Kroll et al., 2011; Hu et al., 2013).

In this study, an Aerodyne high-resolution time-of-flight AMS (HR-ToF-AMS) was deployed at a suburban site in Ziyang, downwind of Chengdu City in the Sichuan Basin, in the heavily polluted winter. We obtained highly timeresolved chemical compositions and size distributions of nonrefractory submicron aerosols $\left(\mathrm{NR}-\mathrm{PM}_{1}\right)$, then apportioned the sources of OA, as well as investigated the secondary formation and aging process of $\mathrm{OA}$ under unique geographical and meteorological conditions. The results will give hints to the mechanism of haze formation and help control the serious air pollution in the Sichuan Basin.

\section{Methodology}

\subsection{Sampling site}

An intensive field campaign was carried out on the campus of a primary school in Ziyang $\left(30.15^{\circ} \mathrm{N}, 104.64^{\circ} \mathrm{E}\right)$ during the wintertime from 3 December 2012 to 5 January 2013. The location of the observation site is shown in Fig. 1, and the topography of the Sichuan Basin is shown in Fig. S1 in the Supplement. There were no obvious industrial sources around this site. Ziyang is a county-level city located in central Sichuan Basin, downwind of Chengdu Plain, and in between two megalopolises $(90 \mathrm{~km}$ south of Chengdu and $260 \mathrm{~km}$ to the west of Chongqing). The observation site was selected and considered to be a fine representative to characterize the air pollution in the Sichuan Basin. The $72 \mathrm{~h}$ backward trajectories of air parcels at Ziyang site at an altitude of $500 \mathrm{~m}$ above ground level during the campaign were calculated by NOAA's HYSPLIT4.9 model (http://www.arl.noaa. gov/HYSPLIT_info.php), starting a new trajectory every $6 \mathrm{~h}$, and the result of clustering is shown in Fig. 1. The stagnant air prevailed in the 1-month campaign due to the basin terrain. The only interruption of the atmospheric isolation was an invasion of long-distance transported air mass from northwestern China accompanied with strong wind on 29 December. Therefore, the atmospheric processes were dominated by the isolated meteorology of the basin.

The HR-ToF-AMS was deployed along with other relevant measurement instruments to characterize chemical compositions of atmospheric submicron aerosols and evaluate the aerosol secondary formation and aging process. This is the first application of the HR-ToF-AMS in the Sichuan Basin. The collocated measurement instruments included a multiangle absorption photometer (MAAP, Thermo Fisher Scien- 


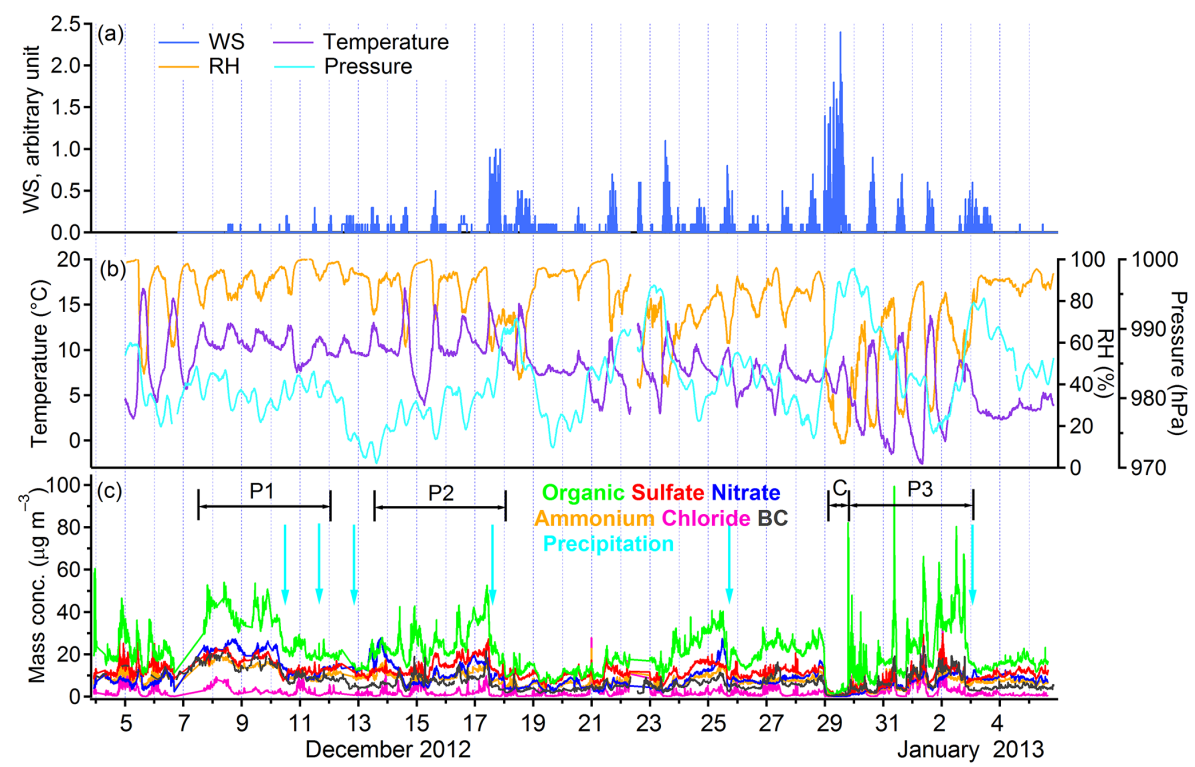

Figure 2. Time series of meteorological parameters and concentrations of chemical compositions in submicron aerosols during the campaign. (a) Wind speed (WS), relative values; (b) relative humidity (RH), temperature and atmospheric pressure; (c) concentrations of chemical compositions in submicron aerosols. Short-term precipitation events are marked by the light blue arrows.

tific Inc.) for $\mathrm{BC}$, online gas chromatography-mass spectrometry/flame ionization detector (GC-MS/FID, TH-017, Wuhan-Tianhong Instrument Co.; Li et al., 2014) and proton transfer reaction mass spectrometer (PTR-MS, Ionicon Analytik $\mathrm{GmbH}$ ) for VOCs and an ambient air quality monitoring system for meteorological parameters, gaseous pollutant concentrations, etc. All instruments were set in two containers placed on the open playground on the campus. The instrument setting, operation and data processing were carried out as described in $\mathrm{Hu}$ et al. (2013). Ambient particles were also collected on the copper mesh at the site on some days during the campaign. Particles were photographed and investigated using the transmission electron microscope coupled with an energy dispersive X-ray spectrometer (TEM-EDX, Tecnai G2 T20, FEI Corp.) in the Electron Microscopy Laboratory of Peking University.

\subsection{HR-ToF-AMS operation and data processing}

The HR-ToF-AMS measures the mass concentrations and size distributions of nonrefractory species in submicron aerosols, including organics, sulfate, nitrate, ammonium and chloride (DeCarlo et al., 2006; Hu et al., 2013).

A $\mathrm{PM}_{2.5}$ impactor inlet was set on the roof of the container to remove coarse particles. The airstream was introduced through a copper tube at a flow rate of $8 \mathrm{~L} \mathrm{~min}^{-1}$ and isokinetically sampled into the HR-ToF-AMS at a flow rate of $0.09 \mathrm{~L} \mathrm{~min}^{-1}$ from the center of the copper tube. Before entering the instrument, the airstream was dried with a Nafion drier (Perma Pure, Inc.) and kept RH below $30 \%$. Because of the generation mechanism of atmospheric $\mathrm{BC}$ particles, they are mostly in the Aitken and accumulation modes, i.e., in the submicron range (Bond et al., 2013). In order to make a better mass closure of refractory species, BC was measured simultaneously at a 5 min time resolution with the MAAP coupled with a $\mathrm{PM}_{2.5}$ cutoff cyclone.

The HR-ToF-AMS operated in a cycle of $5 \mathrm{~min}$ during the campaign. Under the V-mode, it functioned on mass spectrum (MS) mode for $1 \mathrm{~min}$ to obtain the mass concentrations of the nonrefractory species and on a separate PToF (particle time-of-flight) mode for $1.5 \mathrm{~min}$ to determine size distributions of species. Under the W-mode, only high-resolution mass spectral data (HR-MS) was obtained for $2.5 \mathrm{~min}$. The ionization efficiency (IE), sampling flow and particle sizing of HR-ToF-AMS were calibrated following the standard protocols (Drewnick et al., 2005). The calibrations of IE and the particle sizing used size-selected pure ammonium nitrate particles with nominal diameters of 400 and $60-650 \mathrm{~nm}$, respectively. According to the definition of detection limits (DLs) of different species determined by AMS (Huang et al., 2011), the DLs (V-mode) of organics, sulfate, nitrate, ammonium and chloride during the campaign were calculated to be 0.24 , $0.07,0.04,0.05$ and $0.01 \mu \mathrm{g} \mathrm{m}^{-3}$, respectively.

V-Mode provides data with a lower resolution while WMode produces data with a higher one. V-mode data are used to generate unit mass resolution (UMR) spectra, from which mass concentrations and size distributions of species are determined (DeCarlo et al., 2006); W-mode data serve to separate ion fragments with the same nominal $\mathrm{m} / \mathrm{z}$ but different elemental compositions (Aiken et al., 2007). The standard AMS data analysis software packages (SQUIRREL version $1.57 \mathrm{I}$ and PIKA version $1.16 \mathrm{H}$ ), downloaded from 
the ToF-AMS-Resources web page (http://cires.colorado. edu/jimenez-group/ToFAMSResources) and compiled and executed on Igor Pro 6.22A, were used to generate UMR and HR-MS from the V- and W-mode data, respectively. All algorithm results of AMS collection efficiencies (CEs) based on aerosol chemical compositions and sampling line RH (Middlebrook et al., 2012) were approximately 0.5 . Here a CE factor of 0.5 , which performed well in many previous field studies (Aiken et al., 2009), was used to calculate mass concentrations. The default relative ionization efficiency (RIE) values (Jimenez et al., 2003) were applied in this study, except for ammonium for which RIE $=4.04$ was used, assuming $\mathrm{PM}_{1}$ was neutral and other metallic species were ignorable in $\mathrm{PM}_{1}$ (water-soluble $\mathrm{K}^{+}, \mathrm{Ca}^{2+}, \mathrm{Mg}^{2+}$ and $\mathrm{Na}^{+}$were 1.22 , $0.25,0.04$ and $0.21 \mu \mathrm{g} \mathrm{m}^{-3}$ in $\mathrm{PM}_{2.5}$ ). The reported $\mathrm{O} / \mathrm{C}$ and $\mathrm{H} / \mathrm{C}$ ratios of $\mathrm{OA}$ in previous studies were mostly biased low because low $\mathrm{H}_{2} \mathrm{O}^{+} / \mathrm{CO}_{2}^{+}$ratios in OA were widely used (Chen et al., 2015). In this study, the "improved-ambient" correction (Canagaratna et al., 2015) was applied to calculate the $\mathrm{O} / \mathrm{C}$ and $\mathrm{H} / \mathrm{C}$ ratios of OA. The improved-ambient corrected results of elemental ratios reported in previous studies are taken from Canagaratna et al. (2015) and Chen et al. (2015).

The technical details on Aerodyne HR-ToF-AMS data process, as well as the implementation and validation of the PMF results, could be seen in previous papers (e.g., Huang et al., 2010; Hu et al., 2013). The HR-MS ( $m / z$ 12-255) was analyzed by the PMF model to identify major OA components, which can much better separate different OA components than UMR spectra (Aiken et al., 2009; DeCarlo et al., 2010). Elemental analysis of the OA components identified by PMF was carried out with the methods based on HR-MS as described previously (Aiken et al., 2007; Canagaratna et al., 2015). Besides evaluating the reliability and stability of the outcome of PMF model through several parameters (Sect. S3 in the Supplement), the optimum solution can also be evaluated via comparing the output mass spectra with those of the known sources, comparing the time series of factors with external tracers and analyzing the diurnal patterns of different factors (Zhang et al., 2011). The uncentered correlation (UC) coefficient of MS, i.e., the cosine of the angle between a pair of MS as vectors, was also used as a qualitative metric to support factor identification (Ulbrich et al., 2009). The UC coefficients between the MS of OA factors resolved in this study and the single or average MS of OA factors reported in previous studies are listed in Table S2. Based on all the tests, the solution of four factors, $f_{\text {Peak }}=0$ and seed $=0$ was chosen as the optimal one for this analysis.

\section{Results and discussion}

\subsection{Chemical compositions and size distribution of $\mathbf{P M}_{1}$}

\subsubsection{Variations of chemical species}

The time series of main chemical compositions of submicron aerosols and meteorological parameters during the observation period are shown in Fig. 2. Throughout the observation period, the average $\mathrm{PM}_{1}$ mass concentration (sum of NR-PM 1 measured by AMS and BC by MAAP) was $59.7 \pm 24.1 \mu \mathrm{g} \mathrm{m}^{-3}$. The lowest and highest $\mathrm{PM}_{1}$ concentrations were $3.0 \mu \mathrm{g} \mathrm{m}^{-3}$ in 29 December 2012 and $172.5 \mu \mathrm{g} \mathrm{m}^{-3}$ in 1 January 2013, respectively. Organics, accounting for about $36.0 \pm 6.1 \%$ of $\mathrm{PM}_{1}$, were identified as the most abundant components, followed by sulfate $(20.5 \pm 4.7 \%)$, nitrate $(15.0 \pm 5.2 \%)$, ammonium $(13.8 \pm 2.3 \%)$, BC $(11.1 \pm 3.1 \%)$ and chloride $(3.5 \pm 3.5 \%)$. Compared with the reported results in China (Table 1), the submicron aerosol pollution during this campaign was at a higher level. $\mathrm{PM}_{1}$ mass concentration at Ziyang site was comparable to that of Beijing but higher than at other urban (Shanghai and Shenzhen), coastal/background (Backgarden and Changdao Island) and suburban/rural sites (Jiaxing, Kaiping and Heshan). At almost all of these sites, OM dominated submicron aerosols (about 30-40\%); while at Ziyang site, the concentration of BC $\left(6.5 \mu \mathrm{g} \mathrm{m}^{-3}\right)$ was significantly higher among these sites, indicating strong local primary emissions.

To illustrate the factors influencing air pollution, four episodes were selected according to different pollution levels (as Fig. 2c shown), including three pollution periods (episodes P1, P2 and P3) and a clean day (Episode C). The average $\mathrm{PM}_{1}$ mass concentrations during episodes $\mathrm{P} 1$ and $\mathrm{P} 2$ were as high as 91.6 and $71.8 \mu \mathrm{g} \mathrm{m}^{-3}$, respectively. During the whole campaign, calm occurred frequently (Fig. 2a). Only Episode C (29 December) is a perfectly sunny and clean day due to the diffusion effect of strong wind (Fig. 2a). The $\mathrm{PM}_{1}$ concentration plummeted to the lowest level, $7.6 \mu \mathrm{g} \mathrm{m}^{-3}$ on average. However, $\mathrm{PM}_{1}$ concentration boosted rapidly in the following Episode P3 (30 December 2012 to 3 January 2013) due to apparent primary emissions. The concentrations of organics, sulfate, BC and chloride rose to different extents (Table 1 ), and the average $\mathrm{PM}_{1}$ mass concentration was $56.9 \mu \mathrm{g} \mathrm{m}^{-3}$.

The concentrations of secondary inorganic species (SNA, an acronym for sulfate, nitrate and ammonium) increased stepwise during episodes $\mathrm{P} 1$ and $\mathrm{P} 2$, especially for nitrate, with much higher average concentrations (Table 1). The concentrations of SNA correlated well with RH (Pearson correlation coefficient $r=0.536,0.415$ and $0.555, p<0.01$ ), suggesting this was probably induced by the more effective secondary transformation in the humid air. In Episode $\mathrm{C}$, as the strong wind from northwestern China caused at- 


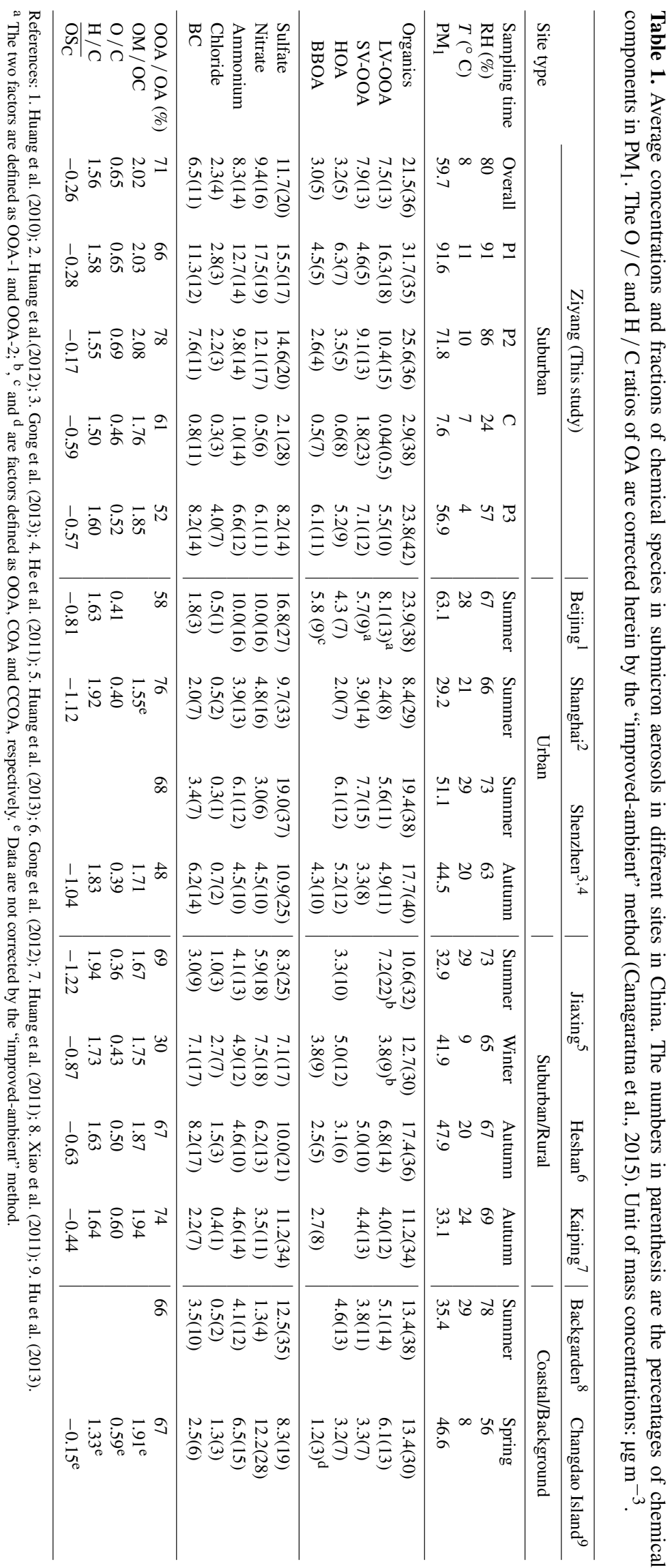



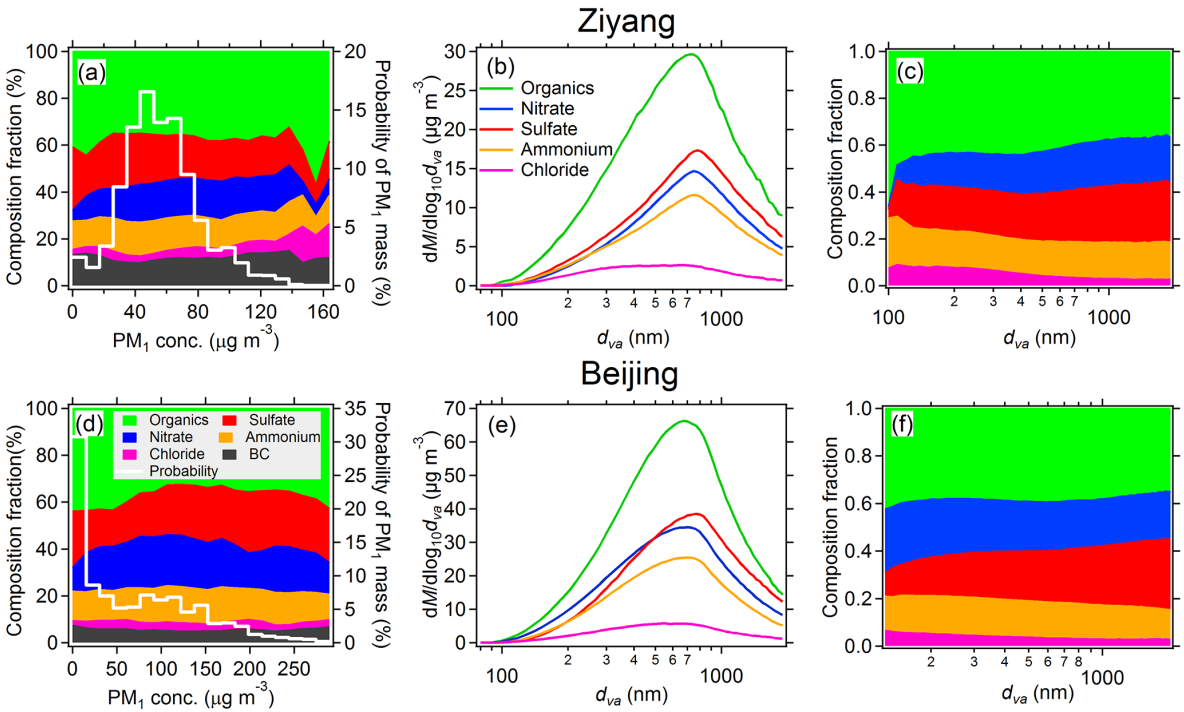

Figure 3. Comparison of the results between Ziyang site (upper) and an urban site in Beijing (lower) near to wintertime. (a, d) Fractions of main chemical components in $\mathrm{PM}_{1}$ as a function of $\mathrm{PM}_{1}$ mass concentrations (left) and the probability density of $\mathrm{PM}_{1}$ mass concentrations (right); (b, e) Average size-resolved mass concentration distributions of chemical species in submicron aerosols; (c, f) Fractions of chemical species in total NR-PM 1 as a function of vacuum aerodynamic size $\left(d_{\mathrm{va}}\right)$.

mospheric pollutant diffusion, the RH decreased to a minimum (Fig. 2b). Each chemical species in submicron aerosols was at the lowest level, which can be considered as the background concentration. The components of organics, sulfate, nitrate, ammonium, BC and chloride accounted for 38.1, 27.5, 6.2, 13.8, 10.9 and $3.4 \%$ of $\mathrm{PM}_{1}$, respectively. In Episode $\mathrm{P} 3$, the proportions of organics, $\mathrm{BC}$ and chloride accounted for $\mathrm{PM}_{1}$ increased due to the strong primary emissions; hence those of SNA decreased. These results reflected the significant impact of meteorology conditions and emission sources on air pollution level.

Since the secondary compositions were dominant in $\mathrm{PM}_{1}$, variation of $\mathrm{PM}_{1}$ depended on secondary formation processes and removal processes, i.e., strong wind and wet deposition. During the campaign, six short-term precipitation events, the main removal approach in Ziyang, were observed, which could eliminate the heavy PM pollution partly (Fig. 2c). However, the humid air after the precipitation may favor the hygroscopic growth of SNA and subsequent condensed/aqueous-phase chemistry, causing the stable or even slightly increased concentrations of SNA (Fig. 2). The probability density of $\mathrm{PM}_{1}$ mass concentration during the campaign followed normal distribution approximately (as the white curve shown in Fig. 3a) and concentrated in a monomode between 30 and $80 \mu \mathrm{g} \mathrm{m}^{-3}$, which was mainly caused by the adverse geological and meteorological conditions. The probability distribution of $\mathrm{PM}_{1}$ mass concentration in Ziyang was similar to that in summer in Beijing, where the stagnant air mass prevented diffusion of pollutants, and high humidity and temperature favored secondary formation (Huang et al., 2010). It contrasted the distribution patterns observed at
Changdao Island (Hu et al., 2013) and in Beijing (23 January to 2 March 2013; Fig. 3d) in the cold period, with broader ranges of $\mathrm{PM}_{1}$ mass concentration. During these two campaigns, clean days appeared more frequently due to the intruding clean air mass carried by strong wind. The probabilities of $\mathrm{PM}_{1}$ mass concentration lower than $35 \mu \mathrm{g} \mathrm{m}^{-3}$ were over $40 \%$, while it was only about $10 \%$ in Ziyang. These results suggested the relatively stable state of submicron aerosol pollution at Ziyang site.

The proportion variations of different chemical species with the increase of $\mathrm{PM}_{1}$ mass concentration are shown in Fig. 3a. The relative contributions of inorganic and organic varied insignificantly, with $\mathrm{PM}_{1}$ mass concentration ranging from 35 to $120 \mu \mathrm{g} \mathrm{m}^{-3}$. When $\mathrm{PM}_{1}$ mass concentration was below $35 \mu \mathrm{g} \mathrm{m}^{-3}$, the fraction of organics increased slightly to $40 \%$ or above. High fractions of organics, chloride and $\mathrm{BC}$ caused by strong primary emissions were found as $\mathrm{PM}_{1}$ was above $140 \mu \mathrm{g} \mathrm{m}^{-3}$.

\subsubsection{Size distribution of chemical species}

The average vacuum aerodynamic $\left(d_{\mathrm{va}}\right)$ size distributions of the nonrefractory species in submicron aerosols are shown in Fig. 3b. Organics and secondary inorganics featured similar size distribution patterns and existed primarily in accumulation mode with peaks centered at $600-800 \mathrm{~nm}$, implying that the particles were internally mixed (Hu et al., 2013, 2016). The TEM images (Fig. 4a-d) also demonstrated that the individual particles were mostly spherical and in the internal mixing state. The peak sizes of all species were larger than those in winter in Beijing (Fig. 3e), Mexico City and Chang- 

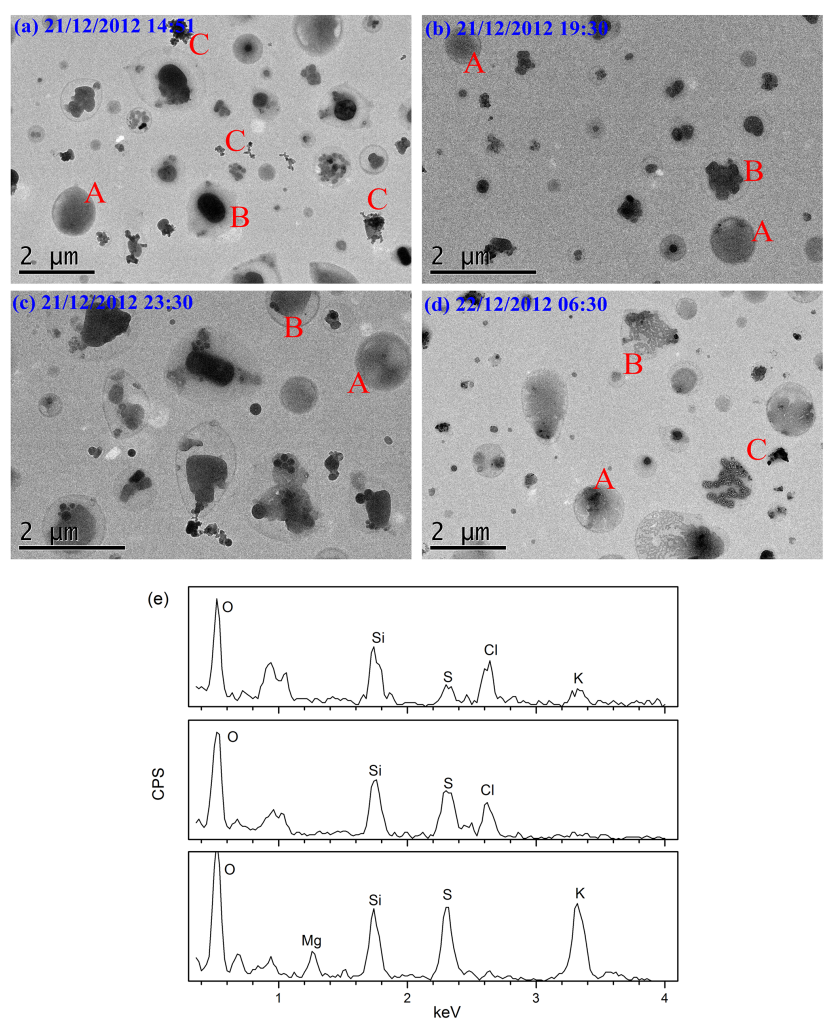

Figure 4. (a-d) Morphology and the mixing state of single particles in hazy days. The predominant particles are spherical ones without or with coating (types A and B), and in internal mixing state; some fresh and aged soot aggregates (type C) were also observed. (e) Examples of elemental compositions in single particles collected. CPS is counts per second.

dao Island (Aiken et al., 2009; Hu et al., 2013), implying that the aqueous reactions under the high RH condition in Ziyang could cause a faster particle growth rate of secondary species than in other areas (Hu et al., 2016). Organics and chloride exhibited broader size distributions than SNA, with obvious mass enhancement at small sizes $(100-500 \mathrm{~nm})$, indicating contributions of primary emissions like biomass burning and coal combustion (Huang et al., 2010; Hu et al., 2013). With the increasing of particle size $\left(d_{\mathrm{va}}>200 \mathrm{~nm}\right)$, the proportion of organics in submicron aerosols decreased slightly, while those of sulfate, nitrate and ammonium increased gradually (Fig. 3c), suggesting that SNA were the main contributors with the growth of particles in Ziyang. In contrast, sulfate made a more significant contribution to particle growth in Beijing winter (Fig. 3f).

\subsection{Investigating OA sources with PMF}

By conducting PMF analysis on the high mass resolution OA spectral matrix, four factors of OA were resolved, i.e., LVOOA, SV-OOA, HOA and BBOA, with distinct mass spectral profiles (Fig. 5) and temporal variations (Fig. 6). They accounted for 34.7, 36.5, 14.9 and $13.9 \%$ of total OA mass, respectively, as shown in Fig. 8a. The former two factors are good surrogates of aged and fresh SOA, while the latter two are classified into POA, respectively (Jimenez et al., 2009). OOA dominated in OA as much as $71 \%$, approximate to or higher than the reported results in China (Table 1), implying the high oxidation state of OA in Ziyang. In total, secondary formation $(\mathrm{OOA}+\mathrm{SNA})$ contributed to $\mathrm{PM}_{1}$ as high as $76 \%$, in accordance with the results of single particle analysis (see Sect. S5). Further strengthening of gaseous precursor's control, therefore, should be pursued.

\subsubsection{Hydrocarbon-like OA}

The average mass spectrum of HOA (Fig. 5) is similar to previously reported reference spectra of HOA (Aiken et al., 2009; Huang et al., 2010, 2011). In this spectrum, alkyl fragments are dominant, especially the saturated alkyl fragments $\left(\mathrm{C}_{n} \mathrm{H}_{2 n+1}^{+}\right)$and the alkenyl fragments $\left(\mathrm{C}_{n} \mathrm{H}_{2 n-1}^{+}\right)$. The $\mathrm{OA} / \mathrm{OC}$ and $\mathrm{O} / \mathrm{C}$ ratios of HOA factor were about 1.31 and 0.10 , respectively, which were approximate to those previous results (OA / OC: 1.34-1.43; O / C: 0.11-0.20) in other areas in China (Canagaratna et al., 2015; He et al., 2011; Huang et al., 2012, 2013; Gong et al., 2012). Factor analysis (e.g., PMF analysis) suffers a limitation, as it is incapable of separating independent sources completely, and the resolved factor may be a mixture of various sources. The abundant characteristic fragments for $\operatorname{COA}(m / z 55,57$, etc. $)$ and CCOA $(m / z 67,69,91$, etc.) can be seen in the mass spectrum of HOA factor (He et al., 2010; Hu et al., 2013). The scatterplot between $f_{55}$ vs. $f_{57}$ in Ziyang is shown in Fig. 7. HOA resolved in this study had high $m / z 55$ vs. $m / z$ 57 ratio of 1.71, which was between the ratios $(2.2-2.8)$ in $\mathrm{COA}$ and those (0.9-1.1) in other non-cooking POA components (Mohr et al., 2012). The ratios of $\mathrm{C}_{3} \mathrm{H}_{3} \mathrm{O}^{+} / \mathrm{C}_{3} \mathrm{H}_{5} \mathrm{O}^{+}$ and $\mathrm{C}_{4} \mathrm{H}_{7}^{+} / \mathrm{C}_{4} \mathrm{H}_{9}^{+}$in $\mathrm{HOA}$ resolved in this study were 1.5 and 1.7 , respectively, which were also in the ranges (1-2 and 1-2.5) between HOA and COA summarized by Mohr et al. (2012). The MS of HOA correlated well with the average MS of HOA factor reported in previous studies, as well as that of COA, BBOA and vehicle-emitted OA (Vehicle-OA) factors (Table S2). HOA tracked well $(r=0.6-0.7, p<0.01)$ with primary source tracers (e.g., chloride, $\mathrm{NO}_{x}, \mathrm{BC}$, acetonitrile, acetaldehyde, toluene and benzene), as shown in Table S3. Among them, chloride and acetonitrile are the tracers of coal combustion and biomass burning emissions, respectively. Thus, it was likely that the HOA factor was a mixture of COA and other POA. The diurnal cycle of HOA presented a peak at around 10:00, which may be related to the living habits of local residents. In rural and suburban areas in southwestern China, residents usually have two meals a day, especially in winter due to short daytime and less labor, so the influence of COA was weaker at noon. 


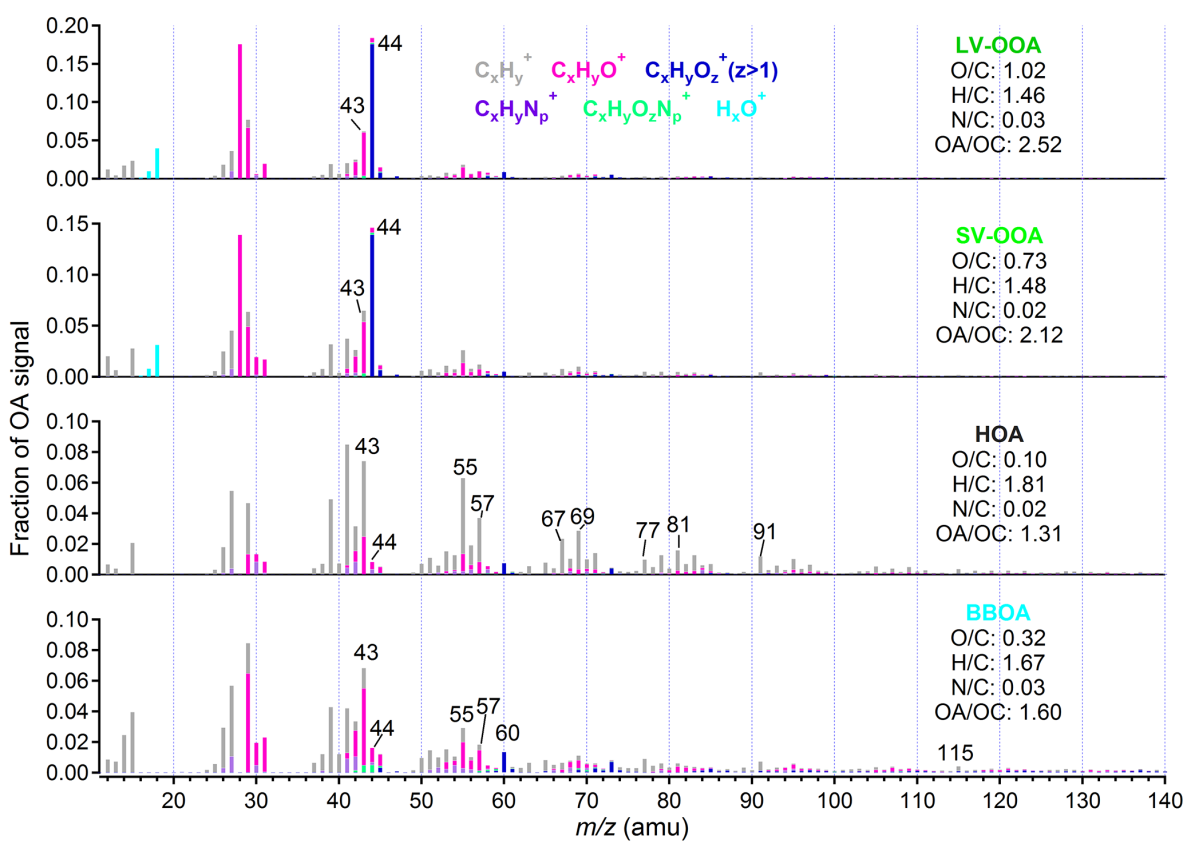

Figure 5. Unit mass spectra of OA factors: LV-OOA, SV-OOA, HOA and BBOA. The elemental ratios and OA / OC ratios of each component are also added.

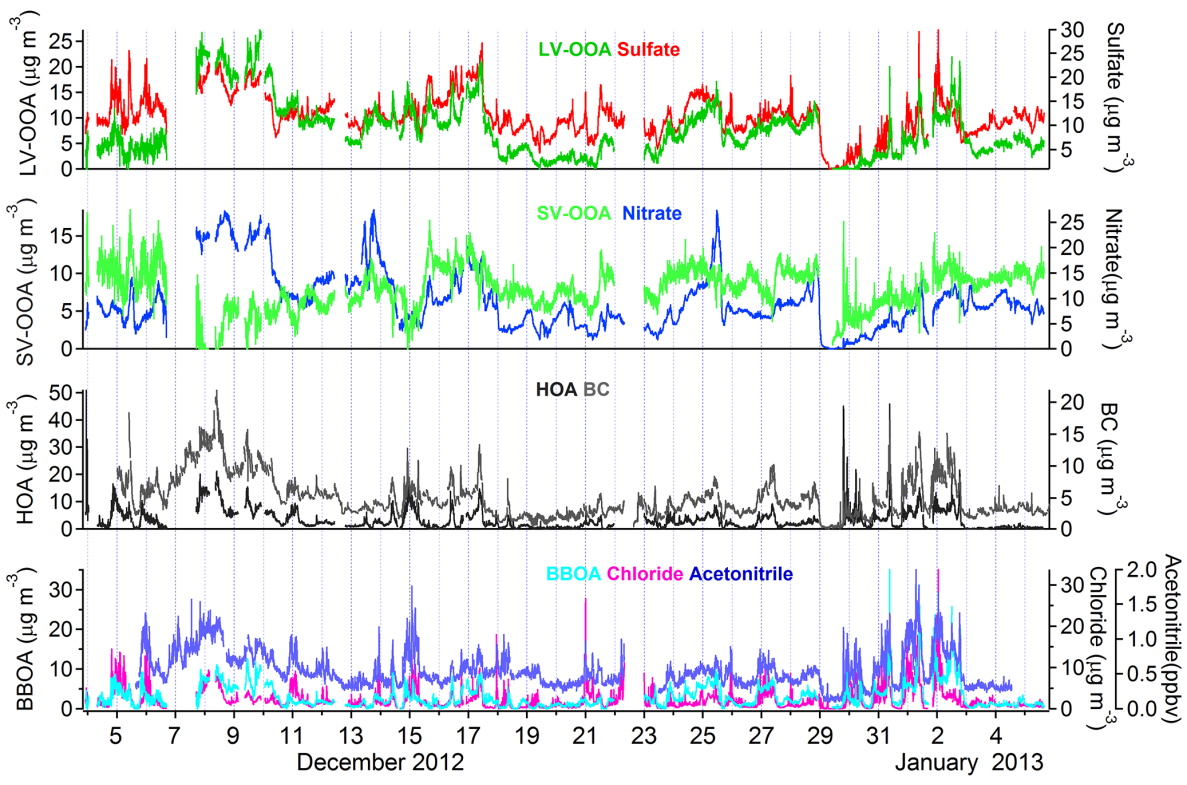

Figure 6. Time series of OA fractions and external tracers (sulfate, nitrate, BC, chloride and acetonitrile).

\subsubsection{Biomass burning $\mathrm{OA}$}

Residential biomass burning plays an important role in aerosol pollution in the winter in southwestern China (Wang et al., 2006; Cao et al., 2012). Levoglucosan is an important tracer of biomass burning aerosols, the fragment of which, $\mathrm{C}_{2} \mathrm{H}_{4} \mathrm{O}_{2}^{+}$, contributed to $m / z 60$ is regarded as a tracer ion of BBOA. The highest abundance of $m / z 60(\sim 1.3 \%)$ is a prominent characteristic in the MS of BBOA factor (Fig. 5), which is much higher than that $(0.3 \%)$ in plumes with negligible biomass burning influence (Cubison et al., 2011). The MS of BBOA resolved in this study showed good correlation with the average MS of BBOA in previous studies (Table S2). In addition, BBOA tracked well with $\mathrm{C}_{2} \mathrm{H}_{4} \mathrm{O}_{2}^{+}$ $(r=0.85, p<0.01)$, further verifying the rationality of the resolved BBOA factor (Table S3). Compared with the O / C ra- 


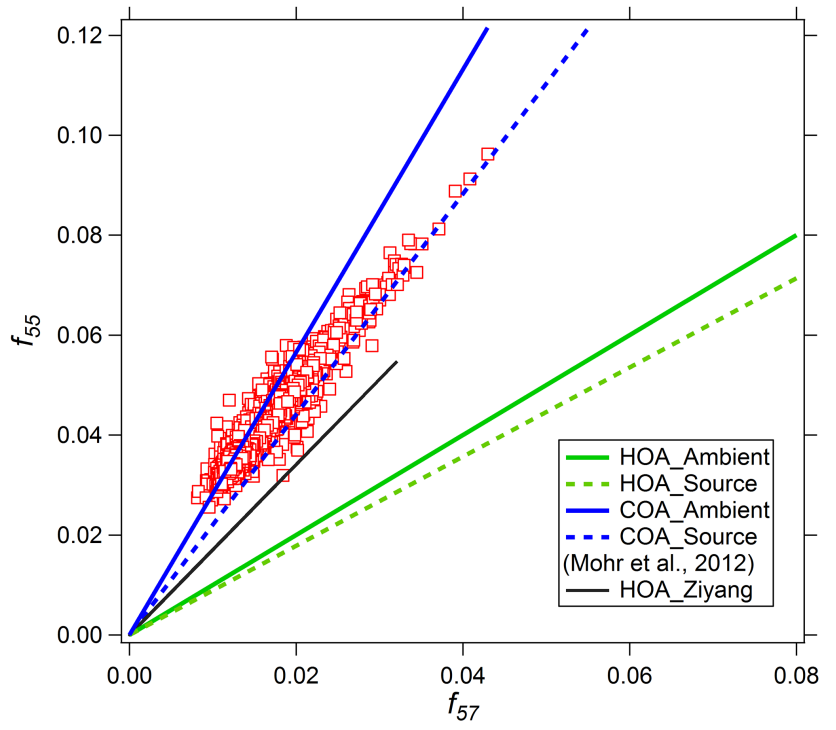

Figure 7. Scatterplot of $f_{55}$ vs. $f_{57}$. The $f_{55}$ vs. $f_{57}$ ratios of "HOA_Ambient" and "COA_Ambient" represent average $f_{55}$ vs. $f_{57}$ values from various PMF HOA and COA factors, and those of "HOA_Source" and "COA_Source" represent $f_{55}$ vs. $f_{57}$ values averaged from several source emission studies reported in Mohr et al. (2012).

tio of HOA (0.10), that (0.32) of BBOA was higher and in the range of $0.25-0.55$ reported previously (Canagaratna et al., 2015). There was a phenomenon of burning straw and wood randomly, especially which is an effective energy for cooking and heating in winter in southern China (Song et al., 2009). High BBOA contribution $(14 \pm 7 \%)$ to OA was consistent with significant biomass burning contribution (9-37\%) to atmospheric VOC species during the same campaign ( $\mathrm{Li}$ et al., 2014). Soot aggregates and sulfur-, chlorine- and potassium-containing particles were observed using TEMEDX (Fig. 4e), also implying that biomass burning was a major contributor to aerosol pollution (See Sect. S5). BBOA was probably emitted from residential houses, makeshift stoves built by migrant workers nearby and waste incineration observationally.

BBOA displayed a very similar diurnal pattern with HOA and $\mathrm{BC}$, with lower concentrations during the daytime and higher ones in the morning and at night (Fig. 8b and Fig. S7), indicating that they may be emitted by similar processes, such as residential emissions via cooking, heating and smoked bacon. Making smoked bacon with biomass (firewood) burning is a traditional and common method of preserving pork in the Sichuan Basin in winter. The previous emission inventory (Guo et al., 2015) showed that residential sources of OA were significant in the Sichuan Basin during the winter 2010 (Fig. 1). All the patterns were likely corresponding to the living habits of local residents as well as the diurnal variation of atmospheric boundary layer. The time series of BBOA tracked well $(r=0.67, p<0.01)$ with an-
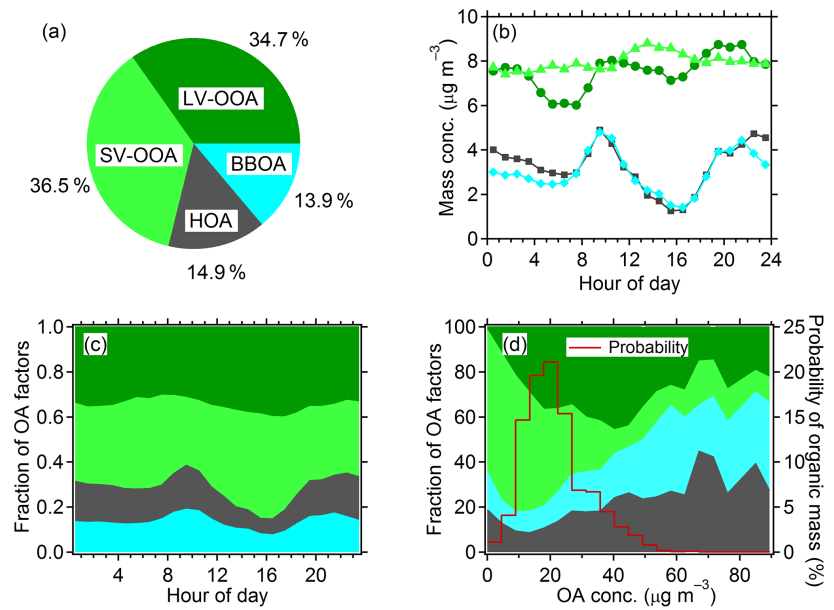

Figure 8. (a) Average mass fraction of each OA component. Diurnal variations of concentrations (b) and fractions in OA (c) for different OA components. (d) Fractions of different OA components in total OA (left) depending on OA concentrations and the probability density of OA concentrations (right).

other tracer of biomass burning events, acetonitrile (Fig. 6 and Table S3). BBOA also presented good correlations with $\mathrm{BC}$ and acetaldehyde (Table S3), which could be partly emitted from biomass burning. In Episode P3, the contributions of BBOA to total OA $(26 \%)$ and $\mathrm{PM}_{1}(11 \%)$ were much higher than those $(10-17 \%, 4-7 \%)$ in other episodes defined above (Table 1), indicating far stronger biomass burning during Episode P3.

\subsubsection{Semivolatile and low-volatility oxygenated OA}

In a large number of studies, OOA has been widely investigated (Zhang et al., 2005; Aiken et al., 2009; $\mathrm{Ng}$ et al., 2011; Hu et al., 2016), which is considered a good alternative to SOA under most conditions (Jimenez et al., 2009; $\mathrm{Ng}$ et al., 2011). As Fig. 5 shown, the identified mass spectra of LV-OOA and SV-OOA are both characterized by the oxygenated fragments $\left(\mathrm{C}_{x} \mathrm{H}_{y} \mathrm{O}_{z}^{+}\right)$, mainly from carboxylic acid and aldehyde, especially $\mathrm{CO}_{2}^{+}\left(\mathrm{m} / z\right.$ 44) and $\mathrm{C}_{2} \mathrm{H}_{3} \mathrm{O}^{+}(\mathrm{m} / z$ 43). The abundance of $\mathrm{C}_{x} \mathrm{H}_{y} \mathrm{O}_{z}^{+}$in LV-OOA was higher than that of SV-OOA. In this study, the abundances of $\mathrm{CO}_{2}^{+}$in LV-OOA and SV-OOA were 18 and $14 \%$, respectively. LVOOA with higher OA / OC and O / C ratios (2.52 and 1.02) was more oxygenated and aged than SV-OOA with lower ratios (2.12 and 0.73). The $\mathrm{O} / \mathrm{C}$ ratios of LV-OOA and SVOOA at Ziyang site were quite higher than the average $\mathrm{O} / \mathrm{C}$ ratios for LV-OOA (0.84) and SV-OOA (0.53) summarized by Canagaratna et al. (2015), indicating that OA was highly oxygenated in Ziyang. Moreover, the effect of biomass burning cannot be completely ruled out, which may also result in higher O / C ratio of SV-OOA.

Generally, OOA tracks well with SNA. LV-OOA correlates better with sulfate, and SV-OOA correlates better with ni- 
trate, for their common volatility. In this study, LV-OOA correlated well with SNA $(r=0.66-0.68, p<0.01)$, while the correlation between SV-OOA and SNA were slightly weaker (Table S3). The time series of SV-OOA roughly trended well towards that of nitrate except in two intervals, 7-10 and 2426 December. The total OOA (LV-OOA and SV-OOA) and secondary inorganic species (sulfate and nitrate) displayed good correlation $(r=0.88, p<0.01)$, in accordance with the dominant secondary origin of OOA. LV-OOA also showed a similar trend to $\mathrm{BC}(r=0.75, p<0.01)$, because the aged $\mathrm{OA}$ can mix well with $\mathrm{BC}$ due to the static air in the basin.

The diurnal variation of LV-OOA showed a valley in the early morning (Fig. 8b, c), and increased from 09:00 to 14:00, indicating a significant secondary formation in the daytime. It displayed another peak in the evening, which may be influenced by the low-volatility particle-phase compounds from biomass burning (Murphy et al., 2014). The SV-OOA concentrations showed a small peak in the afternoon for more efficient photochemical reactions. The fractions of LV-OOA in OA exhibited a relatively stable diurnal pattern, implying LV-OOA was of regional characteristics. The fractions of SV-OOA in total OA varied a little diurnally and only increased slightly to $30 \%$ in the afternoon (13:00-18:00). Conversely, the fractions of HOA and BBOA decreased in the corresponding interval.

Depending on the pollution severity, the contributions of OOA components were distinct. In episodes P1 and P2, OOA was prominent (66 and $76 \%$ ) in OA, and especially LV-OOA dominated in total OOA as 78 and $53 \%$, respectively. In Episode C, SV-OOA predominated in total OA and OOA as high as 61 and $98 \%$, respectively. In Episode P3, POA (sum of HOA and BBOA) and OOA almost contributed equivalently on average, and the contribution (56\%) of SV-OOA to OOA was higher than that of LV-OOA (Table 1).

The proportion of each OA component in total OA as a function of OA concentration and the probability density distribution of OA concentrations are shown in Fig. 8d. OA concentrations were approximately skewed-normally distributed and mainly in the range of $10-40 \mu \mathrm{g} \mathrm{m}^{-3}$. In this range, OOA especially LV-OOA dominated the increase of OA concentration, contributed up to over $80 \%$ of OA. As the OA concentration was below $10 \mu \mathrm{g} \mathrm{m}^{-3}$, SV-OOA transformed from gaseous precursors contributed to OA predominantly. When the OA concentration was greater than $50 \mu \mathrm{g} \mathrm{m}^{-3}$, OA was mainly from strong primary emissions, such as biomass burning. The proportion of LV-OOA and SV-OOA in OA decreased, while the fraction of POA increased dramatically. Specifically, corresponding to strong primary emissions during Episode P3, OA was mainly composed of POA and SV-OOA (as the spikes shown in Fig. 8d) due to the clean background atmosphere. Due to the highly oxidized and aged state of SV-OOA in Ziyang, the MS of SV-OOA was quite similar to that of LV-OOA (Table S2). However, they contributed discriminatively at different OA concentra- tions (Fig. 8d), which should be consistent with the trend of OOA oxidation.

\subsection{Secondary formation and aging process of $\mathrm{OA}$}

\subsubsection{Elemental compositions of OA and VK diagram}

The HR-MS was used to calculate the elemental compositions of OA and OA / OC ratio. During the overall observation period, on average, $\mathrm{C}, \mathrm{H}, \mathrm{O}$ and $\mathrm{N}$ contributed 49.5, $6.4,42.9$ and $1.2 \%$ to the total organic mass, respectively. As for atomic number ratios, the average elemental ratios of $\mathrm{O} / \mathrm{C}, \mathrm{H} / \mathrm{C}$ and $\mathrm{N} / \mathrm{C}$ were $0.65 \pm 0.11,1.56 \pm 0.06$ and $0.02 \pm 0.00$, respectively. The average $\mathrm{O} / \mathrm{C}$ and $\mathrm{H} / \mathrm{C}$ ratios were close to $\mathrm{O} / \mathrm{C}$ ratios $(\sim 0.6)$ for downwind locations and $\mathrm{H} / \mathrm{C}$ ratios $(\sim 1.5)$ for remote/rural locations (Chen et al., 2015). The average OA / OC $(2.02 \pm 0.14$, in the range of 1.37-2.35) and $\mathrm{O} / \mathrm{C}$ ratios were higher than those in urban and suburban/rural areas in China (Table 1), indicating that OA was highly oxidized in Ziyang. Due to primary emissions from 29 December 2012 to 2 January 2013 (Episode P3), the $\mathrm{O} / \mathrm{C}$ ratio declined apparently; while the $\mathrm{H} / \mathrm{C}$ ratio varied oppositely. In episodes $\mathrm{C}$ and $\mathrm{P} 3$, the $\mathrm{O} / \mathrm{C}$ ratios $(0.46,0.52)$ were much lower than those $(0.65,0.69)$ during episodes P1 and P2 (Table 1). As local primary emissions contributing to OA substantially (the uppermost data points in the plot), the $\mathrm{O} / \mathrm{C}$ ratio decreased to the lowest level, and the $\mathrm{H} / \mathrm{C}$ ratio reached up to about 1.9 .

The VK diagram, displaying the variation of $\mathrm{O} / \mathrm{C}$ vs. $\mathrm{H} / \mathrm{C}$, can be used as a tool to probe bulk oxidation reaction mechanisms for organic aerosols ( $\mathrm{Hu}$ et al., 2013). The slope and intercept of VK diagram for OA at Ziyang site was -0.44 $\left(r^{2}=0.70\right)$ and 1.84 , respectively (Fig. 9a). The slope was shallower than those $(-1.0$ to $-0.7,-0.58 \pm 0.04$ for mean fit) observed across the world, which may be more consistent with chemical aging, and the intercept fell into the range (1.8-2.2) for remote/rural sites (Chen et al., 2015). The slope was close to -0.5 , which suggests net changes equivalent to the addition of acid groups with fragmentation and/or both acid and alcohol/peroxide functional groups without fragmentation ( $\mathrm{Ng}$ et al., 2011). During the episodes P1, P2, $\mathrm{C}$ and $\mathrm{P} 3$, the slopes of $\mathrm{VK}$ diagram were $-0.46,-0.57$, -0.84 and -0.52 , respectively. The intercepts of the fitting lines were about 1.87-1.95. This result indicated that carboxylic acid functionalization with fragmentation was dominated during the pollution episodes, while carboxylic acid functionalization without fragmentation or addition of an alcohol and carbonyl group on different carbons was more active during the clean episode.

The photochemical age metric, $-\log \left(\mathrm{NO}_{x} / \mathrm{NO}_{y}\right)$, was used to investigate the relationship between OA oxidation and the photochemical aging. The ratio is higher in the more aged plume (DeCarlo et al., 2008, 2010). When the metric $-\log \left(\mathrm{NO}_{x} / \mathrm{NO}_{y}\right)<0.1$, it is considered to be fresh plume (Liang et al., 1998). Coloring the scatterplot data points in 

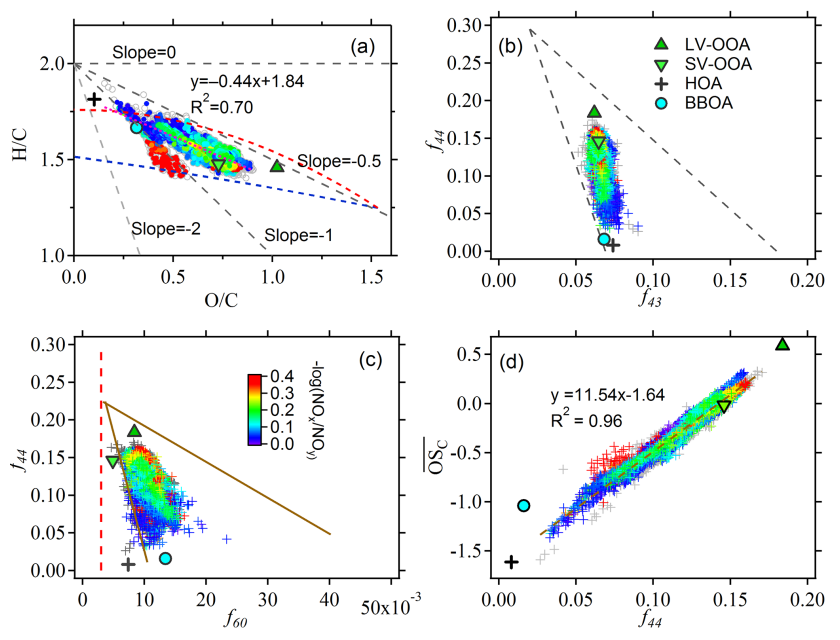

Figure 9. (a) Van Krevelen diagram of organic aerosols. The majority of the data fall into colored triangle lines ( $\mathrm{Ng}$ et al., 2011). (b) Scatterplot of $f_{44}\left(\mathrm{~m} / z, 44\right.$ fraction in organic mass spectra) vs. $f_{43}$. The triangular space defined by dash lines ( $\mathrm{Ng}$ et al., 2011) indicates the region into which the data of OA components fall. (c) Scatterplot of $f_{44}$ vs. $f_{60}$. The conceptual space for BBOA and the nominal background value at $0.3 \%$ (Cubison et al., 2011) are marked by solid and vertical dash lines, respectively. (d) Average carbon oxidation state $\left(\overline{\mathrm{OS}_{\mathrm{C}}}\right)$ vs. $f_{44}$. The scatterplot data points are colored by the photochemical age metric $-\log \left(\mathrm{NO}_{x} / \mathrm{NO}_{y}\right)$. The locations of OA factors are also marked in all diagrams.

VK diagram (Fig. 9a) with $-\log \left(\mathrm{NO}_{x} / \mathrm{NO}_{y}\right)$, there was a clear trend (from the upper left to the lower right) that the aged plumes agreed with higher OA oxidation levels (higher $\mathrm{O} / \mathrm{C}$ ratios), except for the data in the clean day (07:0018:00 29 December; lower middle). The plume was probably well aged photochemically due to strong solar radiation, and the OOA was predominated by freshly formed SV-OOA (Fig. 8d). The OA factors resolved by AMS-PMF analysis are also marked in Fig. 9a. In the order from POA (HOA and BBOA) to SOA (SV-OOA and LV-OOA), the OA factors evolved along with the direction to a higher oxidation state, which was consistent with the oxidation characteristics of the factors (Ng et al., 2011), although SV-OOA evolved along a line with a smooth slope to LV-OOA.

\subsubsection{Triangle plot ( $f_{44}$ vs. $f_{43}$ and $f_{44}$ vs. $\left.f_{60}\right)$}

OA evolution can also be characterized in terms of the varying abundances of the two most dominant oxygen-containing ions in the OOA spectra, $m / z 43$ and $m / z 44$ (mostly $\mathrm{CO}_{2}^{+}$ in ambient data). Since $m / z 44$ is found to be proportional to the acid species, it seems that acid group formation plays a significant role in OOA aging process ( $\mathrm{Ng}$ et al., 2011). The $m / z 43$ fragments are mainly $\mathrm{C}_{2} \mathrm{H}_{3} \mathrm{O}^{+}$, predominantly due to non-acid oxygenates, for the OOA fraction and $\mathrm{C}_{3} \mathrm{H}_{7}^{+}$for the HOA fraction. To avert the effects of atmospheric dispersion and dilution capability, $m / z 43$ and $m / z 44$ fractions in organic mass spectra $\left(f_{43}\right.$ and $\left.f_{44}\right)$ were used to characterize the oxidation of OA.

The scatterplot of $f_{44}$ against $f_{43}$ is shown in Fig. $9 \mathrm{~b}$, and colored with $-\log \left(\mathrm{NO}_{x} / \mathrm{NO}_{y}\right)$. The $f_{44}$ ranged from 0.03 to 0.17 , and the $f_{43}$ was in a narrow range of 0.05 to 0.09 , which fitted the triangle space for OA components (Ng et al., 2011). With increasing photochemical age (-log $\left.\left(\mathrm{NO}_{x} / \mathrm{NO}_{y}\right)\right), f_{44}$ increased and $f_{43}$ decreased, reflecting the photochemical aging of OA (Ng et al., 2010). The locations of OA factors are also marked in the plot. OA showed the evolution trends moving from the bottom (HOA and BBOA, $\left.f_{44}<0.05\right)$ to an intermediate location (SV-OOA) and to the top (LV-OOA) in the triangle. Data points gradually moved upward from the lower half of the triangle with enhancement of OA oxidation in smoke chamber experiments and field observations (Ng et al., 2010). The location of SV-OOA on the upper half of the triangle is close to that of LV-OOA (Fig. 9b), highlighting the high oxidation level of SV-OOA.

The scatterplot of $f_{44}$ against $f_{60}$ (Fig. 9c), colored with $-\log \left(\mathrm{NO}_{x} / \mathrm{NO}_{y}\right)$, was also applied here to facilitate understanding the secondary formation and transformation of primary BBOA in Ziyang. Cubison et al. (2011) reported that in the $f_{44}$ against $f_{60}$ space, data with negligible biomass burning influence were concentrated on the left side as a band shape $\left(f_{60}=0.2-0.4 \%\right)$, while data from biomass burning appeared in the lower right part. Almost all data points fell into the left side of the conceptual space for BBOA (Cubison et al., 2011), indicating the important contribution of biomass burning to OA during the whole observation period. HOA and SV-OOA resolved in this study were located out of the conceptual space for BBOA, while BBOA and LV-OOA were located in it. In addition, $m / z 60$ accounted for $0.8,0.5,0.7$ and $1.3 \%$ of LV-OOA, SV-OOA, HOA and BBOA, respectively. Higher abundance of $m / z 60$ indicated that LV-OOA and HOA were probably associated with biomass burning processes and had been referred to as LV-bbSOA and bbPOA (bb, biomass burning) by Murphy et al. (2014). There was no trend for the variation of $f_{60}$ upon the increase of $-\log$ $\left(\mathrm{NO}_{x} / \mathrm{NO}_{y}\right)$, suggesting that there was no dependence of the contribution of biomass burning to $\mathrm{OA}$ on photochemical aging.

\subsubsection{Average carbon oxidation state of $\mathrm{OA}$}

The average oxidation state of the carbon $\left(\overline{\mathrm{OS}_{\mathrm{C}}} \approx 2 \times \mathrm{O} / \mathrm{C}\right.$ $\mathrm{H} / \mathrm{C}$ ) is an ideal metric for the degree of oxidation of organic species in the atmosphere and serves as a key quantity to describe organic mixtures that are as chemically complex as OA (Kroll et al., 2011). The $\overline{\mathrm{OS}_{\mathrm{C}}}$ in Ziyang was calculated as $-0.26 \pm 0.27$ on average, ranging from -1.59 to 0.36 . It was within the $\overline{\mathrm{OS}_{\mathrm{C}}}$ ranges in downwind and remote/rural environment (Chen et al., 2015), lower than those of ambient OA in the aged (Whistler Mountain) and coastal/background (Changdao Island) atmosphere, much higher than or compa- 


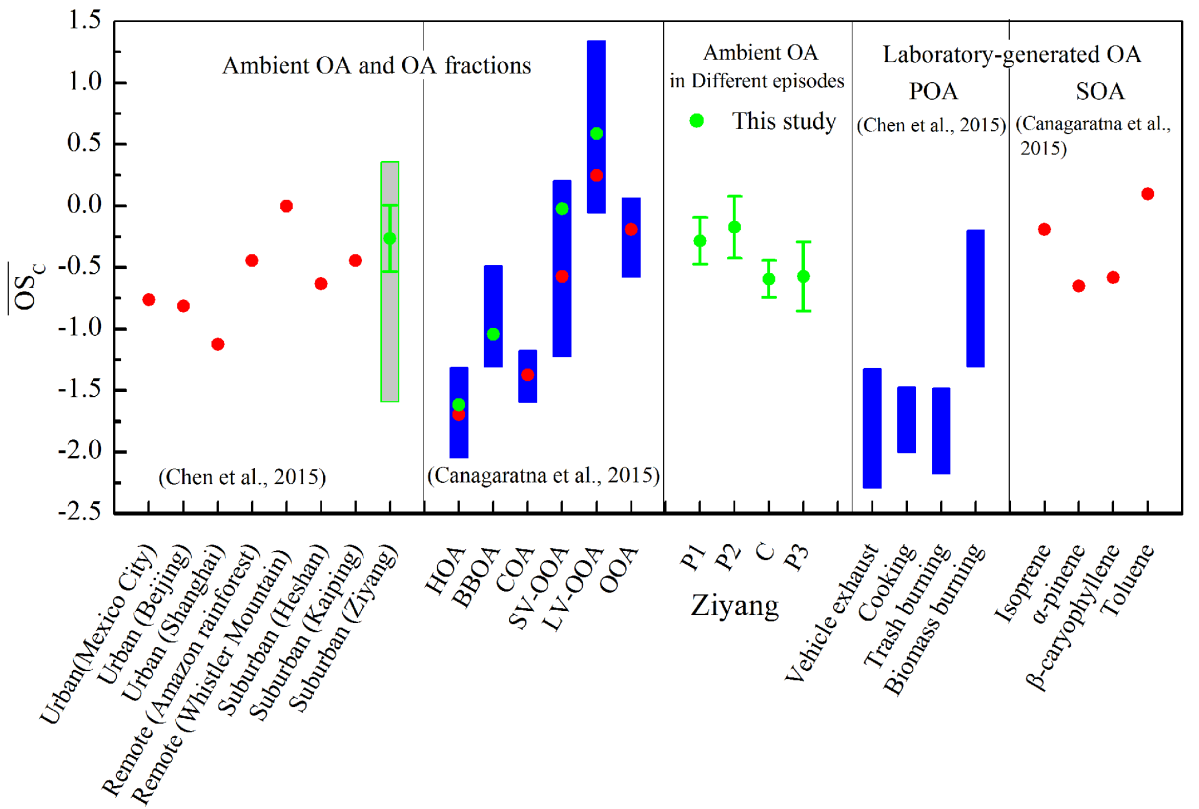

Figure 10. Improved-ambient results of $\overline{\mathrm{OS}_{\mathrm{C}}}$ for OA. The previously reported results are from the summary by Chen et al. (2015) and Canagaratna et al. (2015). The floating bar, dot and error bar mean the range, average and standard deviation of $\overline{\mathrm{OS}_{\mathrm{C}}}$.

rable to those of other urban and suburban sites in China and laboratory-generated POA and SOA (Fig. 10 and Table 1), also implying OA was highly oxygenated.

A strong correlation between $\overline{\mathrm{OS}_{\mathrm{C}}}$ and $f_{44}$ (Fig. 9d) indicated that carboxylic groups can fragment into a large amount of $\mathrm{CO}_{2}^{+}$ions and explained the high $\overline{\mathrm{OS}_{\mathrm{C}}}$ observed. The fitted line for the overall data has a slope of 11.5 and an intercept of -1.64 , suggesting that the $\overline{\mathrm{OS}_{\mathrm{C}}}$ of non-acid moieties in OA was -1.64 . The $-\log \left(\mathrm{NO}_{x} / \mathrm{NO}_{y}\right)$ increased with increasing $\overline{\mathrm{OS}_{\mathrm{C}}}$ and $f_{44}$ (Fig. 9d), indicating that it is a good qualitative clock for photochemical age (DeCarlo et al., 2008), except for the data of 29 December as mentioned above. The average $\overline{\mathrm{OS}_{\mathrm{C}}}$ of HOA, BBOA, SV-OOA and LV-OOA were $-1.61,-1.04,-0.19$ and 0.59 , respectively. The results were in the ranges of previously reported ones (Fig. 10), and in accordance with that $\overline{\mathrm{OS}_{\mathrm{C}}}$ must increase upon oxidation of $\mathrm{OA}$ and those non-acid oxygenated groups may undergo further oxidation during their atmospheric lifetime if conditions permit (Kroll et al., 2011). The $\overline{\mathrm{OS}_{\mathrm{C}}}$ in episodes $\mathrm{C}$ and $\mathrm{P} 3$ was decreased due to the freshly emitted $\mathrm{OA}$; while in episodes $\mathrm{P} 1$ and $\mathrm{P} 2$, the $\overline{\mathrm{OS}_{\mathrm{C}}}$ increased to -0.65 and -0.69 (Fig. 10 and Table 1), indicating the OA during the hazy periods may contain relatively more abundant oxygenated groups other than the carboxylic group, such as carbonyl and hydroxyl groups (Y. J. Li et al., 2013).

\subsubsection{Evolution of $\mathrm{OA} / \Delta \mathrm{CO}$ ratio with chemical conversions}

In order to understand the effects of chemical conversions on the properties of $\mathrm{OA}$ in the atmosphere, it is neces- sary to avoid the influences of emissions and transport of OA by normalizing OA to a relatively inert combustion tracer over the timescales of interest, e.g., CO (de Gouw and Jimenez, 2009). The OA / $\triangle \mathrm{CO}$ ratios are used to evaluate the secondary formation of $\mathrm{OA}$, where $\triangle \mathrm{CO}$ indicates that the regional background concentration of $\mathrm{CO}$ $(0.2$ ppmv, the average concentration in Episode C) has been subtracted. OA / $\triangle \mathrm{CO}$ ratio is lower for the primary emission plume from source region and becomes higher after substantial SOA formation (DeCarlo et al., 2010). The average $\mathrm{OA} / \triangle \mathrm{CO}$ ratio in Ziyang during the campaign was $41.7 \pm 23.0 \mu \mathrm{g} \mathrm{m}^{-3} \mathrm{ppmv}^{-1}$, which was lower than the average level $\left(70 \pm 20 \mu \mathrm{g} \mathrm{m}^{-3} \mathrm{ppmv}^{-1}\right)$ around the world (de Gouw and Jimenez, 2009). In more polluted periods, SOA / $\triangle \mathrm{CO}$ accounted for $70-80 \%$ of OA / $\Delta \mathrm{CO}$, implying higher contribution of secondary formation. The influence of biomass burning emission can also cause high $\mathrm{OA} / \triangle \mathrm{CO}$ ratio, often similar to or even higher than SOA / $\triangle$ CO ratio from aged plumes (Cubison et al., 2011). In Episode P3, the OA / $\triangle \mathrm{CO}$ reached the highest value as $209.2 \mu \mathrm{g} \mathrm{m}^{-3} \mathrm{ppmv}^{-1}$. It was similar to the ever reported highest results $210 \mu \mathrm{g} \mathrm{m}^{-3} \mathrm{ppmv}^{-1}$ in Mexico City when influenced by strong biomass burning emissions (DeCarlo et al., 2010), indicating the important contribution of biomass burning to OA. Furthermore, SV-OOA / $\triangle \mathrm{CO}$ increased from 7.7 (P1) and 16.1 (P2) to $19.8 \mu \mathrm{g} \mathrm{m}^{-3} \mathrm{ppmv}^{-1}$ for SV-OOA can be quickly formed in the plumes.

Photochemical age was calculated using ratios of $\mathrm{m}+\mathrm{p}$ xylene to ethylbenzene concentrations with an initial emission ratio of $2.2 \mathrm{ppbv} \mathrm{ppbv}^{-1}$ (Fig. S8, Yuan et al., 2013). 
The average $\mathrm{OH}$ radical concentration applied here is $1.6 \times$ $10^{6}$ molecule $\mathrm{cm}^{-3}$ in order to compare with other studies (DeCarlo et al., 2010; Hu et al., 2013). A detailed description of the determination of photochemical age can be found in Yuan et al. (2013). The variations of PMF resolved OA factors to $\triangle \mathrm{CO}$ as a function of photochemical age are shown in Fig. 11a. With the increase of photochemical age, POA components (BBOA and HOA) maintained a stable level, implying the stable background concentration of POA in the daytime. However, SOA surrogate components (LV-OOA and SV-OOA) enhanced with the increase of photochemical age, which was consistent with the photochemical processing of OA. Specifically, the regression slopes of average LV-OOA / $\triangle \mathrm{CO}$ and SVOOA / $\triangle \mathrm{CO}$ vs. photochemical age in the range of 2.6$7.1 \mathrm{~h}$ were 0.48 and $0.60 \mu \mathrm{g} \mathrm{m}^{-3} \mathrm{ppmv}^{-1} \mathrm{~h}^{-1}$ (Fig. S9), respectively, which may result from the efficient secondary formations from plenty of emitted POA, especially BBOA (Robinson et al., 2007). The increasing slope of OA $\left(1.2 \mu \mathrm{g} \mathrm{m}^{-3} \mathrm{ppmv}^{-1} \mathrm{~h}^{-1}\right)$, which was approximate to that at Changdao Island $\left(1.3 \mu \mathrm{g} \mathrm{m}^{-3} \mathrm{ppmv}^{-1} \mathrm{~h}^{-1}\right)$ and lower than those $\left(\sim 2-5 \mathrm{ppmv}^{-1} \mathrm{~h}^{-1}\right)$ in Mexico City and the USA ( $\mathrm{Hu}$ et al., 2013), was almost completely attributed to the contribution of SOA. As the photochemical age was longer than $7 \mathrm{~h}$, the average OA / $\triangle \mathrm{CO}$ ratio decreased with the photochemical age, caused by the decrease of LV-OOA / $\Delta \mathrm{CO}$ ratio (Fig. 11a). Atmospheric oxidation of OA converges toward greatly aged LV-OOA despite of the original OA sources (Jimenez et al., 2009). Given the concentrations of OA components in aged air during this campaign, the evolution from POA to SV-OOA and to LV-OOA may be inhibited by lower concentration of POA (about one-third of those in fresh air), resulting in lower LV-OOA concentrations but relatively stable SV-OOA concentrations because SV-OOA was already dominant in OA (Jimenez et al., 2009).

The average fractions of OA components in total OA at each bin vs. the photochemical age are shown in Fig. 11b. OOA dominated OA (56-84\%) in both fresh and aged plumes, suggesting a high oxidation state of OA. When the photochemical age was nominally very short, POA (HOA+BBOA) accounted for $44 \%$ of total OA. While, due to the unique geographical and meteorological conditions in the basin terrain, it is reasonable that the aged OA mixed with freshly emitted gaseous pollutants in the air, resulting in the substantial fraction of OOA at low apparent ages $(\mathrm{Hu}$ et al., 2013). The POA fraction in total OA decreased rapidly with the increasing of photochemical age. As the photochemical age longer than $6 \mathrm{~h}$, the percentage of SV-OOA (54\%) was much higher than that of LV-OOA $(27 \%)$ in total OA (Fig. 11), implying that the photochemical formation of SVOOA was more efficiently than that of LV-OOA.

The good correlations between OOA and $\mathrm{O}_{x}$ $\left(\mathrm{O}_{x}=\mathrm{O}_{3}+\mathrm{NO}_{2}\right.$, surrogate of total oxidant $)$ were considered to be useful for empirical predictions of SOA productions in previous studies in Mexico City and Houston
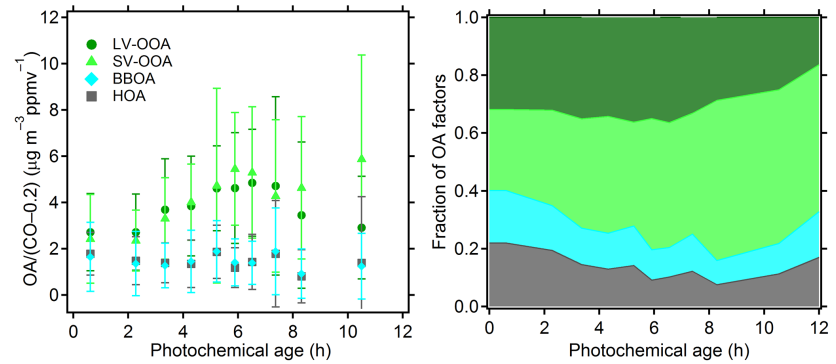

Figure 11. (a) The variations of LV-OOA / $\Delta \mathrm{CO}$, SV-OOA / $\Delta \mathrm{CO}$, $\mathrm{BBOA} / \triangle \mathrm{CO}$ and HOA / $\triangle \mathrm{CO}$ with the photochemical age. The dot point and bar in each photochemical age bin are the average value and standard deviation. (b) Mass fraction of each OA component as a function of photochemical age. The photochemical age is classified into 10 bins by decile.

(Herndon et al., 2008; Wood et al., 2010). However, OOA did not correlate well with $\mathrm{O}_{x}$ in Ziyang (Fig. S10), indicating the SOA formation mechanisms in Ziyang differed greatly from those in Mexico City and Houston. The RH in Ziyang during the campaign was $80 \pm 19 \%(12-100 \%)$ on average (Table 1) and reached saturation frequently. From the OOA vs. $\mathrm{O}_{x}$ scatterplot color-coded using $\mathrm{RH}$, it can be found that the slope of OOA against $\mathrm{O}_{x}$ steepened with the increasing RH (Fig. S10), indicating that both photochemical and aqueous-phase oxidation can dominate the secondary formation of OA in the atmosphere in Ziyang (Hu et al., 2016). In drier air $(\mathrm{RH}<40 \%)$, OOA formation was dominated by photochemical processes, while the aqueous-phase oxidation probably became a more significant and efficient approach to $\mathrm{OOA}$ production in humid atmosphere $(\mathrm{RH}>40 \%)$ in Ziyang.

\section{Conclusions}

We investigated the chemical compositions of atmospheric submicron aerosols with a HR-ToF-AMS at a suburban site, Ziyang, located in the Sichuan Basin, China, during the wintertime from December 2012 to January 2013. This study provided a special case of studying the characteristics and sources of aerosol pollution under the specific geographical and meteorological conditions in the basin terrain.

The mass concentrations of $\mathrm{PM}_{1}$ maintained a moderate level $\left(59.7 \pm 24.1 \mu \mathrm{g} \mathrm{m}^{-3}\right)$ during the whole campaign. $\mathrm{OA}$ was the most abundant $\mathrm{PM}_{1}$ component $(36 \%)$. High $\mathrm{OA} / \mathrm{OC}$ and $\mathrm{O} / \mathrm{C}$ ratios and average carbon oxidation state indicated that OA were in a high oxidation state. Using AMS-PMF analysis, four OA fractions defined as LVOOA (34.7\%), SV-OOA (36.5\%), HOA (14.9\%) and BBOA $(13.9 \%)$ were identified. Secondary formation contributed predominantly to OA (71\%) and $\mathrm{PM}_{1}(76 \%)$. Secondary inorganic species (SNA) contributed significantly to the heavy aerosol pollution due to the more effective secondary forma- 
tion and hygroscopic growth in the humid air. The OA factors evolved along with the direction to a higher oxidation state, from POA (HOA and BBOA) to SOA (SV-OOA and LVOOA). With the increase of photochemical age, OA became more aged with higher oxidation state (higher $\mathrm{O} / \mathrm{C}$ ratio, $f_{44}$ and $\overline{\mathrm{OS}_{\mathrm{C}}}$ ), and LV-OOA / $\triangle \mathrm{CO}$ and SV-OOA / $\Delta \mathrm{CO}$ also increased, implying photochemical processing contributed significantly to OA. The photochemical formation of SV-OOA was more efficient than that of LV-OOA during this campaign. The aqueous-phase oxidation can also contribute significantly to SOA production in humid atmosphere, with the $\mathrm{OOA} / \mathrm{O}_{x}$ ratio and $\mathrm{RH}$ increased simultaneously to some extent.

The concentration and proportion of $\mathrm{BC}$ in $\mathrm{PM}_{1}$ at Ziyang site were at a much higher level among those reported results in China, indicating the severe primary emissions. During the episode obviously affected by primary emissions, the contributions of $\mathrm{BBOA}$ to $\mathrm{OA}$ and $\mathrm{PM}_{1}$ were much higher than those in other polluted episodes, highlighting the critical influence of biomass burning.

These results provide a better understanding of the role of primary emissions and secondary formation in submicron aerosol pollution in the Sichuan Basin. In the future, further work should be done to elucidate more details of the haze formation mechanisms and to assess the effects of aerosol pollution in the Sichuan Basin.

\section{Data availability}

The data presented in this article are available from the authors upon request (minhu@pku.edu.cn).

\section{The Supplement related to this article is available online at doi:10.5194/acp-16-13213-2016-supplement.}

Acknowledgements. This work was supported by the National Basic Research Program of China (2013CB228503), the Strategic Priority Research Program of the Chinese Academy of Sciences (XDB05010500) and the China Ministry of Environmental Protection's Special Funds for Scientific Research on Public Welfare (20130916). We would like to thank the observation team in Ziyang for their kind help, in particular for Sichuan Provincial Monitoring Center. We appreciate D. R. Worsnop, S. Guo and J. Peng for their helpful comments, Z. Gong for his guidance of data processing, Q. Zhang for sharing the database of Multi-resolution Emission Inventory for China (MEIC) and Y. Tian and J. Morrow for their English polishing.

Edited by: A. Carlton

Reviewed by: two anonymous referees

\section{References}

Aiken, A. C., DeCarlo, P. F., and Jimenez, J. L.: Elemental Analysis of Organic Species with Electron Ionization High-Resolution Mass Spectrometry, Anal. Chem., 79, 8350-8358, 2007.

Aiken, A. C., Salcedo, D., Cubison, M. J., Huffman, J. A., DeCarlo, P. F., Ulbrich, I. M., Docherty, K. S., Sueper, D., Kimmel, J. R., Worsnop, D. R., Trimborn, A., Northway, M., Stone, E. A., Schauer, J. J., Volkamer, R. M., Fortner, E., de Foy, B., Wang, J., Laskin, A., Shutthanandan, V., Zheng, J., Zhang, R., Gaffney, J., Marley, N. A., Paredes-Miranda, G., Arnott, W. P., Molina, L. T., Sosa, G., and Jimenez, J. L.: Mexico City aerosol analysis during MILAGRO using high resolution aerosol mass spectrometry at the urban supersite (T0) - Part 1: Fine particle composition and organic source apportionment, Atmos. Chem. Phys., 9, 6633-6653, doi:10.5194/acp-9-6633-2009, 2009.

Allan, J. D., Williams, P. I., Morgan, W. T., Martin, C. L., Flynn, M. J., Lee, J., Nemitz, E., Phillips, G. J., Gallagher, M. W., and Coe, H.: Contributions from transport, solid fuel burning and cooking to primary organic aerosols in two UK cities, Atmos. Chem. Phys., 10, 647-668, doi:10.5194/acp-10-647-2010, 2010.

Bond, T. C., Doherty, S. J., Fahey, D. W., Forster, P. M., Berntsen, T., DeAngelo, B. J., Flanner, M. G., Ghan, S., Kärcher, B., Koch, D., Kinne, S., Kondo, Y., Quinn, P. K., Sarofim, M. C., Schultz, M. G., Schulz, M., Venkataraman, C., Zhang, H., Zhang, S., Bellouin, N., Guttikunda, S. K., Hopke, P. K., Jacobson, M. Z., Kaiser, J. W., Klimont, Z., Lohmann, U., Schwarz, J. P., Shindell, D., Storelvmo, T., Warren, S. G., and Zender, C. S.: Bounding the role of black carbon in the climate system: A scientific assessment, J. Geophys. Res.-Atmos., 118, 5380-5552, 2013.

Canagaratna, M. R., Jimenez, J. L., Kroll, J. H., Chen, Q., Kessler, S. H., Massoli, P., Hildebrandt Ruiz, L., Fortner, E., Williams, L. R., Wilson, K. R., Surratt, J. D., Donahue, N. M., Jayne, J. T., and Worsnop, D. R.: Elemental ratio measurements of organic compounds using aerosol mass spectrometry: characterization, improved calibration, and implications, Atmos. Chem. Phys., 15, 253-272, doi:10.5194/acp-15-253-2015, 2015.

Cao, J. J., Shen, Z. X., Chow, J. C., Watson, J. G., Lee, S.-C., Tie, X.-X., Ho, K.-F., Wang, G.-H., and Han, Y.-M.: Winter and Summer $\mathrm{PM}_{2.5}$ Chemical Compositions in Fourteen Chinese Cities, J. Air Waste Manage. Assoc., 62, 1214-1226, 2012.

Carlton, A. G., Wiedinmyer, C., and Kroll, J. H.: A review of Secondary Organic Aerosol (SOA) formation from isoprene, Atmos. Chem. Phys., 9, 4987-5005, doi:10.5194/acp-9-4987-2009, 2009.

Chen, Q., Heald, C. L., Jimenez, J. L., Canagaratna, M. R., Zhang, Q., He, L.-Y., Huang, X.-F., Campuzano-Jost, P., Palm, B. B., Poulain, L., Kuwata, M., Martin, S. T., Abbatt, J. P. D., Lee, A. K. Y., and Liggio, J.: Elemental composition of organic aerosol: The gap between ambient and laboratory measurements, Geophys. Res. Lett., 42, 4182-4189, doi:10.1002/2015GL063693, 2015.

Chen, Y. and Xie, S.: Temporal and spatial visibility trends in the Sichuan Basin, China, 1973 to 2010, Atmos. Res., 112, 25-34, 2012.

Chen, Y. and Xie, S.: Long-term trends and characteristics of visibility in two megacities in southwest China: Chengdu and Chongqing, J. Air Waste Manage. Assoc., 63, 1058-1069, 2013.

Cubison, M. J., Ortega, A. M., Hayes, P. L., Farmer, D. K., Day, D., Lechner, M. J., Brune, W. H., Apel, E., Diskin, G. S., Fisher, 
J. A., Fuelberg, H. E., Hecobian, A., Knapp, D. J., Mikoviny, T., Riemer, D., Sachse, G. W., Sessions, W., Weber, R. J., Weinheimer, A. J., Wisthaler, A., and Jimenez, J. L.: Effects of aging on organic aerosol from open biomass burning smoke in aircraft and laboratory studies, Atmos. Chem. Phys., 11, 12049-12064, doi:10.5194/acp-11-12049-2011, 2011.

DeCarlo, P. F., Kimmel, J. R., Trimborn, A., Northway, M. J., Jayne, J. T., Aiken, A. C., Gonin, M., Fuhrer, K., Horvath, T., and Docherty, K. S.: Field-deployable, high-resolution, time-of-flight aerosol mass spectrometer, Anal. Chem., 78, 8281-8289, 2006.

DeCarlo, P. F., Dunlea, E. J., Kimmel, J. R., Aiken, A. C., Sueper, D., Crounse, J., Wennberg, P. O., Emmons, L., Shinozuka, Y., Clarke, A., Zhou, J., Tomlinson, J., Collins, D. R., Knapp, D., Weinheimer, A. J., Montzka, D. D., Campos, T., and Jimenez, J. L.: Fast airborne aerosol size and chemistry measurements above Mexico City and Central Mexico during the MILAGRO campaign, Atmos. Chem. Phys., 8, 4027-4048, doi:10.5194/acp-84027-2008, 2008.

DeCarlo, P. F., Ulbrich, I. M., Crounse, J., de Foy, B., Dunlea, E. J., Aiken, A. C., Knapp, D., Weinheimer, A. J., Campos, T., Wennberg, P. O., and Jimenez, J. L.: Investigation of the sources and processing of organic aerosol over the Central Mexican Plateau from aircraft measurements during MILAGRO, Atmos. Chem. Phys., 10, 5257-5280, doi:10.5194/acp-10-52572010, 2010.

de Gouw, J. and Jimenez, J. L.: Organic Aerosols in the Earth's Atmosphere, Environ. Sci. Tech., 43, 7614-7618, 2009.

Drewnick, F., Hings, S., DeCarlo, P., Jayne, J., Gonin, M., Fuhrer, K., Weimer, S., Jimenez, J., Demerjian, K., Borrmann, S., and Worsnop, D.: A New Time-of-Flight Aerosol Mass Spectrometer (TOF-AMS)-Instrument Description and First Field Deployment, Aerosol Sci. Tech., 39, 637-658, 2005.

Gong, Z., Lan, Z., Xue, L., Zeng, L., He, L., and Huang, X.: Characterization of submicron aerosols in the urban outflow of the central Pearl River Delta region of China, Front. Environ. Sci. Eng., 6, 725-733, 2012.

Gong, Z., Xue, L., Sun, T., Deng, Y., He, L., and Huang, X.: Online measurement of $\mathrm{PM}_{1}$ chemical composition and size distribution using a high-resolution aerosol mass spectrometer during 2011 Shenzhen Universiade, Scientia Sinica Chimica, 43, 363372, doi:10.1360/032012-384, 2013.

Guo, Q., Hu, M., Guo, S., Wu, Z., Hu, W., Peng, J., Hu, W., Wu, Y., Yuan, B., Zhang, Q., and Song, Y.: The identification of source regions of black carbon at a receptor site off the eastern coast of China, Atmos. Environ., 100, 78-84, 2015.

Hallquist, M., Wenger, J. C., Baltensperger, U., Rudich, Y., Simpson, D., Claeys, M., Dommen, J., Donahue, N. M., George, C., Goldstein, A. H., Hamilton, J. F., Herrmann, H., Hoffmann, T., Iinuma, Y., Jang, M., Jenkin, M. E., Jimenez, J. L., Kiendler-Scharr, A., Maenhaut, W., McFiggans, G., Mentel, Th. F., Monod, A., Prévôt, A. S. H., Seinfeld, J. H., Surratt, J. D., Szmigielski, R., and Wildt, J.: The formation, properties and impact of secondary organic aerosol: current and emerging issues, Atmos. Chem. Phys., 9, 5155-5236, doi:10.5194/acp-9-51552009, 2009.

He, K.: Multi-resolution Emission Inventory for China (MEIC): model framework and 1990-2010 anthropogenic emissions, AGU Fall Meeting Abstracts, Vol. 1, p. 5, 2012.
He, L.-Y., Lin, Y., Huang, X.-F., Guo, S., Xue, L., Su, Q., Hu, M., Luan, S.-J., and Zhang, Y.-H.: Characterization of highresolution aerosol mass spectra of primary organic aerosol emissions from Chinese cooking and biomass burning, Atmos. Chem. Phys., 10, 11535-11543, doi:10.5194/acp-10-11535-2010, 2010.

He, L. Y., Huang, X. F., Xue, L., Hu, M., Lin, Y., Zheng, J., Zhang, R., and Zhang, Y. H.: Submicron aerosol analysis and organic source apportionment in an urban atmosphere in Pearl River Delta of China using high-resolution aerosol mass spectrometry, J. Geophys. Res.-Atmos., 116, D12304, doi:10.1029/2010JD014566, 2011.

Herndon, S. C., Onasch, T. B., Wood, E. C., Kroll, J. H., Canagaratna, M. R., Jayne, J. T., Zavala, M. A., Knighton, W. B., Mazzoleni, C., Dubey, M. K., Ulbrich, I. M., Jimenez, J. L., Seila, R., de Gouw, J. A., de Foy, B., Fast, J., Molina, L. T., Kolb, C. E., and Worsnop, D. R.: Correlation of secondary organic aerosol with odd oxygen in Mexico City, Geophys. Res. Lett., 35, L15804, doi:10.1029/2008GL034058, 2008.

Hu, W. W., Hu, M., Yuan, B., Jimenez, J. L., Tang, Q., Peng, J. F., Hu, W., Shao, M., Wang, M., Zeng, L. M., Wu, Y. S., Gong, Z. H., Huang, X. F., and He, L. Y.: Insights on organic aerosol aging and the influence of coal combustion at a regional receptor site of central eastern China, Atmos. Chem. Phys., 13, 10095-10112, doi:10.5194/acp-13-10095-2013, 2013.

Hu, W. W., Hu, M., Hu, W., Jimenez, J. L., Yuan, B., Chen, W., Wang, M., Wu, Y., Chen, C., Wang, Z., Peng, J., Yang, K., Zeng, L., and Shao, M.: Chemical composition, sources and aging process of sub-micron aerosols in Beijing: contrast between summer and winter, J. Geophys. Res.-Atmos., 121, 1955-1977, doi:10.1002/2015JD024020, 2016.

Huang, X.-F., He, L.-Y., Hu, M., Canagaratna, M. R., Sun, Y., Zhang, Q., Zhu, T., Xue, L., Zeng, L.-W., Liu, X.-G., Zhang, Y.-H., Jayne, J. T., Ng, N. L., and Worsnop, D. R.: Highly time-resolved chemical characterization of atmospheric submicron particles during 2008 Beijing Olympic Games using an Aerodyne High-Resolution Aerosol Mass Spectrometer, Atmos. Chem. Phys., 10, 8933-8945, doi:10.5194/acp-10-8933-2010, 2010.

Huang, X.-F., He, L.-Y., Hu, M., Canagaratna, M. R., Kroll, J. H., Ng, N. L., Zhang, Y.-H., Lin, Y., Xue, L., Sun, T.-L., Liu, X.-G., Shao, M., Jayne, J. T., and Worsnop, D. R.: Characterization of submicron aerosols at a rural site in Pearl River Delta of China using an Aerodyne High-Resolution Aerosol Mass Spectrometer, Atmos. Chem. Phys., 11, 1865-1877, doi:10.5194/acp-11-18652011, 2011.

Huang, X.-F., He, L.-Y., Xue, L., Sun, T.-L., Zeng, L.-W., Gong, Z.-H., Hu, M., and Zhu, T.: Highly time-resolved chemical characterization of atmospheric fine particles during 2010 Shanghai World Expo, Atmos. Chem. Phys., 12, 4897-4907, doi:10.5194/acp-12-4897-2012, 2012.

Huang, X. F., Xue, L., Tian, X. D., Shao, W. W., Sun, T. L., Gong, Z. H., Ju, W. W., Jiang, B., Hu, M., and He, L. Y.: Highly timeresolved carbonaceous aerosol characterization in Yangtze River Delta of China: Composition, mixing state and secondary formation, Atmos. Environ., 64, 200-207, 2013.

Jimenez, J. L., Jayne, J. T., Shi, Q., Kolb, C. E., Worsnop, D. R., Yourshaw, I., Seinfeld, J. H., Flagan, R. C., Zhang, X. F., Smith, K. A., Morris, J. W., and Davidovits, P.: Ambient aerosol sampling using the Aerodyne Aerosol Mass Spectrometer, J. 
Geophys. Res.-Atmos., 108, 8425, doi:10.1029/2001JD001213, 2003.

Jimenez, J. L., Canagaratna, M. R., Donahue, N. M., Prevot, A. S. H., Zhang, Q., Kroll, J. H., DeCarlo, P. F., Allan, J. D., Coe, H., Ng, N. L., Aiken, A. C., Docherty, K. S., Ulbrich, I. M., Grieshop, A. P., Robinson, A. L., Duplissy, J., Smith, J. D., Wilson, K. R., Lanz, V. A., Hueglin, C., Sun, Y. L., Tian, J., Laaksonen, A., Raatikainen, T., Rautiainen, J., Vaattovaara, P., Ehn, M., Kulmala, M., Tomlinson, J. M., Collins, D. R., Cubison, M. J., Dunlea, J., Huffman, J. A., Onasch, T. B., Alfarra, M. R., Williams, P. I., Bower, K., Kondo, Y., Schneider, J., Drewnick, F., Borrmann, S., Weimer, S., Demerjian, K., Salcedo, D., Cottrell, L., Griffin, R., Takami, A., Miyoshi, T., Hatakeyama, S., Shimono, A., Sun, J. Y., Zhang, Y. M., Dzepina, K., Kimmel, J. R., Sueper, D., Jayne, J. T., Herndon, S. C., Trimborn, A. M., Williams, L. R., Wood, E. C., Middlebrook, A. M., Kolb, C. E., Baltensperger, U., and Worsnop, D. R.: Evolution of Organic Aerosols in the Atmosphere, Science, 326, 1525-1529, 2009.

Kroll, J. H., Ng, N. L., Murphy, S. M., Varutbangkul, V., Flagan, R. C., and Seinfeld, J. H.: Chamber studies of secondary organic aerosol growth by reactive uptake of simple carbonyl compounds, J. Geophys. Res.-Atmos., 110, D23207, doi:10.1029/2005JD006004, 2005.

Kroll, J. H., Donahue, N. M., Jimenez, J. L., Kessler, S. H., Canagaratna, M. R., Wilson, K. R., Altieri, K. E., Mazzoleni, L. R., Wozniak, A. S., Bluhm, H., Mysak, E. R., Smith, J. D., Kolb, C. E., and Worsnop, D. R.: Carbon oxidation state as a metric for describing the chemistry of atmospheric organic aerosol, Nat. Chem., 3, 133-139, 2011

Li, L., Dai, D., Deng, S., Feng, J., Zhao, M., Wu, J., Liu, L., Yang, X., Wu, S., Qi, H., Yang, G., Zhang, X., Wang, Y., and Zhang, Y.: Concentration, distribution and variation of polar organic aerosol tracers in Ya'an, a middle-sized city in western China, Atmos. Res., 120-121, 29-42, 2013.

Li, L., Chen, Y., Zeng, L., Shao, M., Xie, S., Chen, W., Lu, S., $\mathrm{Wu}, \mathrm{Y}$., and Cao, W.: Biomass burning contribution to ambient volatile organic compounds (VOCs) in the Chengdu-Chongqing Region (CCR), China, Atmos. Environ., 99, 403-410, 2014.

Li, Y. J., Lee, B. Y. L., Yu, J. Z., Ng, N. L., and Chan, C. K.: Evaluating the degree of oxygenation of organic aerosol during foggy and hazy days in Hong Kong using high-resolution time-offlight aerosol mass spectrometry (HR-ToF-AMS), Atmos. Chem. Phys., 13, 8739-8753, doi:10.5194/acp-13-8739-2013, 2013.

Liang, J., Horowitz, L. W., Jacob, D. J., Wang, Y., Fiore, A. M., Logan, J. A., Gardner, G. M., and Munger, J. W.: Seasonal budgets of reactive nitrogen species and ozone over the United States, and export fluxes to the global atmosphere, J. Geophys. Res.-Atmos., 103, 13435-13450, 1998.

Luo, Y., Zheng, X., Zhao, T., and Chen, J.: A climatology of aerosol optical depth over China from recent 10-years of MODIS remote sensing data, Int. J. Climatol., 34, 863-870, 2014.

Middlebrook, A. M., Bahreini, R., Jimenez, J. L., and Canagaratna, M. R.: Evaluation of composition-dependent collection efficiencies for the Aerodyne aerosol mass spectrometer using field data, Aerosol. Sci. Tech., 46, 258-271, 2012.

Mohr, C., DeCarlo, P. F., Heringa, M. F., Chirico, R., Slowik, J. G., Richter, R., Reche, C., Alastuey, A., Querol, X., Seco, R., Peñuelas, J., Jiménez, J. L., Crippa, M., Zimmermann, R., Baltensperger, U., and Prévôt, A. S. H.: Identification and quan- tification of organic aerosol from cooking and other sources in Barcelona using aerosol mass spectrometer data, Atmos. Chem. Phys., 12, 1649-1665, doi:10.5194/acp-12-1649-2012, 2012.

Murphy, B. N., Donahue, N. M., Robinson, A. L., and Pandis, S. N.: A naming convention for atmospheric organic aerosol, Atmos. Chem. Phys., 14, 5825-5839, doi:10.5194/acp-14-58252014, 2014.

Ng, N. L., Canagaratna, M. R., Zhang, Q., Jimenez, J. L., Tian, J., Ulbrich, I. M., Kroll, J. H., Docherty, K. S., Chhabra, P. S., Bahreini, R., Murphy, S. M., Seinfeld, J. H., Hildebrandt, L., Donahue, N. M., DeCarlo, P. F., Lanz, V. A., Prévôt, A. S. H., Dinar, E., Rudich, Y., and Worsnop, D. R.: Organic aerosol components observed in Northern Hemispheric datasets from Aerosol Mass Spectrometry, Atmos. Chem. Phys., 10, 46254641, doi:10.5194/acp-10-4625-2010, 2010.

Ng, N. L., Canagaratna, M. R., Jimenez, J. L., Chhabra, P. S., Seinfeld, J. H., and Worsnop, D. R.: Changes in organic aerosol composition with aging inferred from aerosol mass spectra, Atmos. Chem. Phys., 11, 6465-6474, doi:10.5194/acp-11-64652011, 2011.

Niu, H., Cheng, W., Hu, W., and Pian, W.: Characteristics of individual particles in a severe short-period haze episode induced by biomass burning in Beijing, Atmos. Pollut. Res., doi:10.1016/j.apr.2016.05.011, online first, 2016.

Paatero, P.: Least squares formulation of robust non-negative factor analysis, Chemom. Intell. Lab. Syst., 37, 23-35, 1997.

Robinson, A. L., Donahue, N. M., Shrivastava, M. K., Weitkamp, E. A., Sage, A. M., Grieshop, A. P., Lane, T. E., Pierce, J. R., and Pandis, S. N.: Rethinking organic aerosols: Semivolatile emissions and photochemical aging, Science, 315, 1259-1262, 2007.

Song, Y., Liu, B., Miao, W., Chang, D., and Zhang, Y.: Spatiotemporal variation in nonagricultural open fire emissions in China from 2000 to 2007, Global Biogeochem. Cy., 23, GB2008, doi:10.1029/2008GB003344, 2009.

Ulbrich, I. M., Canagaratna, M. R., Zhang, Q., Worsnop, D. R., and Jimenez, J. L.: Interpretation of organic components from Positive Matrix Factorization of aerosol mass spectrometric data, Atmos. Chem. Phys., 9, 2891-2918, doi:10.5194/acp-9-2891-2009, 2009.

Wang, G. H., Kawamura, K., Lee, S., Ho, K. F., and Cao, J. J.: Molecular, seasonal, and spatial distributions of organic aerosols from fourteen Chinese cities, Environ. Sci. Tech., 40, 46194625, 2006.

Wang, Q. Y., Cao, J. J., Tao, J., Li, N., Su, X. O., Chen, L. W. A., Wang, P., Shen, Z. X., Liu, S. X., and Dai, W. T.: Long-Term Trends in Visibility and at Chengdu, China, Plos One, 8, e68894, doi:10.1371/journal.pone.0068894, 2013.

Wood, E. C., Canagaratna, M. R., Herndon, S. C., Onasch, T. B., Kolb, C. E., Worsnop, D. R., Kroll, J. H., Knighton, W. B., Seila, R., Zavala, M., Molina, L. T., DeCarlo, P. F., Jimenez, J. L., Weinheimer, A. J., Knapp, D. J., Jobson, B. T., Stutz, J., Kuster, W. C., and Williams, E. J.: Investigation of the correlation between odd oxygen and secondary organic aerosol in Mexico City and Houston, Atmos. Chem. Phys., 10, 8947-8968, doi:10.5194/acp-10-8947-2010, 2010.

Xiao, R., Takegawa, N., Zheng, M., Kondo, Y., Miyazaki, Y., Miyakawa, T., Hu, M., Shao, M., Zeng, L., Gong, Y., Lu, K., Deng, Z., Zhao, Y., and Zhang, Y. H.: Characterization and source apportionment of submicron aerosol with aerosol mass 
spectrometer during the PRIDE-PRD 2006 campaign, Atmos. Chem. Phys., 11, 6911-6929, doi:10.5194/acp-11-6911-2011, 2011.

Yang, F., Tan, J., Zhao, Q., Du, Z., He, K., Ma, Y., Duan, F., Chen, G., and Zhao, Q.: Characteristics of $\mathrm{PM}_{2.5}$ speciation in representative megacities and across China, Atmos. Chem. Phys., 11, 5207-5219, doi:10.5194/acp-11-5207-2011, 2011.

Yuan, B., Hu, W. W., Shao, M., Wang, M., Chen, W. T., Lu, S. H., Zeng, L. M., and Hu, M.: VOC emissions, evolutions and contributions to SOA formation at a receptor site in eastern China, Atmos. Chem. Phys., 13, 8815-8832, doi:10.5194/acp-13-88152013, 2013.

Zhang, Q., Alfarra, M. R., Worsnop, D. R., Allan, J. D., Coe, H., Canagaratna, M. R., and Jimenez, J. L.: Deconvolution and quantification of hydrocarbon-like and oxygenated organic aerosols based on aerosol mass spectrometry, Environ. Sci. Tech., 39, 4938-4952, 2005.

Zhang, Q., Jimenez, J. L., Canagaratna, M. R., Allan, J. D., Coe, H., Ulbrich, I., Alfarra, M. R., Takami, A., Middlebrook, A. M., Sun, Y. L., Dzepina, K., Dunlea, E., Docherty, K., DeCarlo, P. F., Salcedo, D., Onasch, T., Jayne, J. T., Miyoshi, T., Shimono, A., Hatakeyama, S., Takegawa, N., Kondo, Y., Schneider, J., Drewnick, F., Borrmann, S., Weimer, S., Demerjian, K., Williams, P., Bower, K., Bahreini, R., Cottrell, L., Griffin, R. J., Rautiainen, J., Sun, J. Y., Zhang, Y. M., and Worsnop, D. R.: Ubiquity and dominance of oxygenated species in organic aerosols in anthropogenically-influenced Northern Hemisphere midlatitudes, Geophys. Res. Lett., 34, L13801, doi:10.1029/2007GL029979, 2007.
Zhang, Q., Jimenez, J. L., Canagaratna, M. R., Ulbrich, I. M., Ng, N. L., Worsnop, D. R., and Sun, Y.: Understanding atmospheric organic aerosols via factor analysis of aerosol mass spectrometry: a review, Anal. Bioanal. Chem., 401, 3045-3067, 2011.

Zhang, X. Y., Wang, Y. Q., Zhang, X. C., Guo, W., and Gong, S. L.: Carbonaceous aerosol composition over various regions of China during 2006, J. Geophys. Res.-Atmos., 113, D14111, doi:10.1029/2007JD009525, 2008. 